\title{
3 INTRODUCTION
}

\subsection{The legacy of Johannes Bobrowski}

Johannes Bobrowski (1917-1965), one of the most distinguished German post Second World War writers, is known to his readers through his lyrical works, particularly Sarmatische Zeit (1961), Schattenland Ströme (1962 / 63), Wetterzeichen (1966 / 67), and his two novels Levins Mühle (1964) and Litauische Claviere (1966). Although his Opera Omnia (Complete Works) in six volumes were published 1987-1999, some manuscript material, housed in the Marbach archives, was not included ${ }^{1}$. In Marbach there is an unpublished copybook in Bobrowski's handwriting containing an Old Prussian (OP) word list (referred to as Pruzzische Vokabeln (abbrev. PV, cf. Appendix A, as distinct from my Old Prussian Glossary, abbrev. OPG) of 583 lemmata in total, which, though referred to in critical literature, has not been evaluated $^{2}$. The purpose of the current publication is to bring it to the attention of scholars world-wide. Bobrowski's word list relies primarily on the so-called Elbing Vocabulary $(E)$, the oldest and most important OP glossary, the Enchiridion (Enchiridion Der kleine Catechismus, abbrev. Enchiridion or its OP translation, Stas Likuts Catechismus, usuallly referred to as Catechismus III, abbrev. $K I I I$ ), as well as other sources, to be discussed here.

Bobrowski's $P V$ is unique in that it is the only collection of $\mathrm{OP}$ words by a modern East German writer, who became famous on both sides of the former Iron Curtain from the mid-1960's and beyond. However, the significance of his $P V$ has not been recognized to date. The reason for Bobrowski's collection of OP

\footnotetext{
${ }^{1}$ Although Bobrowski's works started appearing in print in 1961, the first four of the planned six volumes (1-4), first edition, did not see the light until 1987. The first five volumes include his poetry, his novels and short stories, commentary and notes (5). All were edited by Eberhard Haufe. For the last volume (6) Holger Gehle provided comments and notes on both the poems and the novels, as well as the short stories and miscellaneous prose and materials relating to Bobrowski's Selbstzeugnisse ('personal testimonials', i.e. articles relating to his autobiography, poetic texts, reviews, disparate interviews, etc. published 1987-1999).

2 The Marbach archival entry reads as follows: Konv. Pruzzische Vokabeln mit deutscher Übersetzung, 1 Ringbuch=19 beschr. Bl .u. 32 leere Bl.; 91.2.95.
} 
'hard to get' books for this enterprise: Petras Aras, Arthur Hermann, A. Karazijenè, R. Lipšienè, Pranciška Regina Liubertaite and the Lithuanian Library in Melbourne. I should like to thank the Marbach Archives for permission to publish the $P V$ as well as for procuring a CD with scans of Bobrowski's $P V$. I would like to thank Pranciška Regina Liubertaite for checking the Lithuanian sections, my publisher Prof. August Obermayer (University of Otago) for his patience and Prof. Dr. Grasilda Blažiene (Institute of the Lithuanian Language in Vilnius), who made valuable suggestions. A special vote of thanks goes to Assoc. Prof. Dino Bressan (University of Melbourne) for his careful reading of the manuscript as well as being an unfailing and untiring support throughout the project. Any remaining inaccuracies are solely my responsibility. 
words is not entirely clear. It could have been merely a 'spare time' hobby. The more likely view is that, due to his declared affinity to the old Prussians, he may have wanted to delve further into OP and use it for his ensuing work. More specifically, Bobrowski's linguistic interest should enable us to shed a new light on his strong focus on Old Prussian and Lithuanian themes, reflected in both his prose and lyrical output. This $O P G$ incorporates the corpus of Bobrowski's own words and will be discussed under the aspect of five main groups. They include:
A. Fauna and flora;
B. Religion;
C. Inanimate natural features;
D. Grammatical Items;
E. The sphere of the human being and Other.

These groups have been classified more or less along semantic lines. Most groups have been sub-divided and are more finely tuned, thus permitting an easier typological overview. Bobrowski's selection, including the headwords, meanings and, in some cases, proper names, highlights his own particular interests (cf. 7.1, Principle of Selectivity, below). The Classification of the $P V$, including all five groups and a statistical overview, is to be found in Appendix B.

Although the present work, the $O P G$, primarily aims at publishing Bobrowski's $P V$, it cannot be entirely separated from his literary activities. It becomes evident that Bobrowski does not subject his word list to any specified historical or modern linguistic scrutiny. The $O P G$ thus presents Bobrowski's $P V$ with the present writer's annotations and, whenever feasible, includes references to Bobrowski's literary works.

\subsection{The manuscript, use of the Gothic script, alphabetical sequence, sources and content of the OP vocabulary}

The word list contains 583 headwords. The words are neatly written in a ring exercise book consisting of 25 handwritten pages. The cover page states that 19 pages ( 25 pages, kb) have been written on and that 32 pages are blank. Bobrowski wrote the OP words in Latin (Roman) script, listing the entries in approximate alphabetical order, beginning with the OP word for river (1 ape 'Fluß' Angerapp) and finishing with the word for evil-doer (583 wargu seggientins 'Übeltäter'). Next to each entry is a German 
translation written in Gothic cursive script, developed in its known German from the 15th century up to its classical form in the 18th century. It was still in official use for the German language until circa $1946^{3}$. It was, however, still practised after the Second World War, as Bobrowski's own usage in the $P V$, where he applies the Gothic script for both the German meanings and the PN (cf. also his copious correspondence), well illustrates. In some cases he includes toponyms, less frequently hydronyms and anthroponyms (as well as appellatives). In extremely rare cases, a Lithuanian word has been added. However, Bobrowski sometimes departs from the Gothic in the writing of capital letters, which very closely resemble the Latin script. Generally speaking, the words are easy to read. A sample of Bobrowski's manuscript has been reproduced in Appendix $A$.

\subsection{The relationship between Bobrowski's OP Vocabulary and his Lithuanian and OP themes}

Bobrowski had a long-standing and continuing interest not only in Lithuanian themes in general but also in the Old Prussian society. This is documented in particular in his collections of poetry titled Sarmatische Zeit and Wetterzeichen. The poems Pruzzische Elegie (PE), Gestorbene Sprache (GS) and Namen für den Verfolgten (NV) are included there. His novel Litauische Claviere (LC) was completed in July 1965 and published posthumously ${ }^{4}$. This bears out the impression that the OP theme was an integral, motivating and on-going aspect of his creative output. However, Bobrowski's interest in Prussian themes went beyond creative writing. In his poems, GS, which includes four OP words, and $N V$, which incorporates two OP words, discussed below, he demonstrates that his $P V$ was used to re-affirm his close bond to the language and culture of the Old Prussians. First written on 17.04.1960 (Haufe, $J B 5,33-34$ ), the poem $P E$ was included in the

${ }^{3}<$ http://en.wikipedia.org/wiki/Blackletter>, accessed 01.04.08.

${ }^{4}$ Litauische Claviere, begun in February 1964, was completed in July 1965 and was published posthumously in May 1966 (Haufe, $J B 6151$. Pruzzische Elegie, dating from 1952, was first published in Sinn und Form in 1955 (Haufe, JB 133-35; notes: Haufe, JB 5, 38-39; abbrev. PE) - Gestorbene Sprache was written on 17.04.1960 (Haufe, JB 126 ; notes: Haufe, JB 5 33-34; abbrev. GS; and Namen für den Verfolgten on 15.8.1963 (Haufe, JB 1191; notes: Gehlen, JB $6197-198$ abbrev. NF). 
Sarmatische Zeit manuscript but was taken out at the request of his publisher. Bobrowski replaced it with $G S$, explaining that, in including it, he was at least retaining the theme of his lieben Pruzzen'.

Bobrowski's interest in East Prussia, to which he always maintained a strong allegiance, was the place where the writer had spent his childhood and formative years (1917-1927). It was associated with his fondest early memories (als die Tage alle vollhingen noch von erhellten Kinderspielen, traumweiten, PE; JB 133). In 1928 he moved to Königsberg, East Prussia, the centre of Baltic studies up to World War II. Not least was Königsberg an important centre of science, culture and education, a famous domain of i.a. Johann Georg Hamann, Immanuel Kant, E.T.A. Hoffmann and many others. One should note in particular, however, the achievements of the Baltic-German scholars and societies, which Bobrowski specifies as 'die Herren Professores und Doctores, Philologen, Ethnologen, Ethnographen, vergleichende Märchenforscher, Etymologen und die Deutsch Litauische Gesellschaft' (LC, JB 3231).

The larger context for Bobrowski's OP themes is the wider one of Sarmatia, the area in Eastern Europe between the Vistula, Volga and the Caspian Sea. It was named after an Indo-European nomadic people, the Sarmatians (Haufe, JB 5 16-17). John Wieczorek's Between -Sarmatia and Socialism is a detailed presentation of this theme $e^{5}$. Bobrowski used a map to highlight with a thick line five geographic areas of literary interest ${ }^{6}$. The zones are described as follows: zone 1 former East and West Prussia, zone 2 Lithuania, Latvia, Estonia and southern Finland; zone 3 Russia, including Siberia as far South as the Black Sea; zone 4 Poland and zone 5, the Baltic Sea as far as Southern Sweden. The concept Sarmatia is included in the title of his collection of poetry Sarmatische Zeit (1961). The poem PE was initially called Altpreußische Elegie. This is the first time he uses the term altpreußisch ('Old Prussian'). In a statement to the

${ }^{5}$ John Wieczorek: Between Sarmatia and Socialism. The Life and Works of Johannes Bobrowski. Amsterdam-Atlanta 1999 (=Amsterdamer Publikationen zur Sprache und Literatur, 139).

${ }^{6}$ Card No 75 Europäisches Rußland, Vol.16 of the Großer Brockhaus, 1933, quoted in: Haufe, $J B 517$. Bobrowski's map is reproduced in Gerhard Wolf: Beschreibung eines Zimmers. 15 Kapitel über Johannes Bobrowski. Stuttgart: Deutsche Verlags-Anstalt 1972, 16. 
publisher Vandenbroeck he said he considered the $P E$ as his best poem. Soon after writing this poem, Bobrowski wrote to Hans Ricke 11.08.1952 stating that the Altpreußische Elegie dealt with the destruction of the Prussians to whom he refers as Pruzzen. This is a reference to the ethnic communities / tribes in the area of later West- and East Prussia who were conquered by the German Order in early 13 th century. Despite the fact that the form Pruzzen is, according to Haufe, incorrect, Bobrowski continued to use the word in his works. Later he wrote to his relative Georg Bobrowski (26.04 and 07.05.1958) that he nurtured a long-enduring bitterness since his childhood, rejecting the historian Treitschke's evaluation of the Crusading State established by the Teutonic Knights. He noted that the $P E$ does not mean to pose the question of justice so much as it wishes to convey a lively impression of his youth and his memories of 'Wallburgen, Grabhügel, Steinbilder' (hill forts, burial mounds, images in stone $)^{7}$. He added that in his studies he had not gone any further than what he found in Ludwig v. Bazcko's History of Prussia and Johann Voigt's work of the same name ${ }^{8}$. In Haufe's view the first volumes of Voigt sympathize with the Pruzzen, even if, according to Haufe, they present a romantic picture of historical events. What Bobrowski didn't agree with at all was $H$. Treitschke's work Das deutsche Ordensland Preußen (1862) which formed a basis for nationalistic propaganda during the Third Reich. However, even before this, Bobrowski's attitude to the Old Prussians had been shaped by his school experiences in Königsberg. These included the views of the writer Alfred Brust (1891-1934) as well as Walter Harich (1898-1931), both of whom he specifically mentions. He later writes to Gertrud Menz (widow of the director of the Königsberg Gymnasium) that the $P E$ expresses his aversion towards the German Order (used synonymously with Crusaders in the present work) and that it stems from his time as a schoolboy: The Pruzzen, he writes, were to him something like the Boers or the native Americans had been for his parent generation. The glorification of the Order by the Nazis, he adds, had also had a negative influence on him.

${ }^{7}$ Cf. Johannes Bobrowski's letter to Georg Bobrowski in 1958, Haufe, $J B$ 539.

${ }^{8}$ Ludwig v. Bazcko: Geschichte Preußens, 6 vol., 1792-1800; Johann Voigt: Geschichte Preußens von den ältesten Zeiten bis zum Untergang der Herrschaft des Deutschen Ordens, 9 vol., 1827-1839, both quoted in Haufe, JB 539. 
Bobrowski's attitude coincides with that of the Lithuanian poet, Wilhelm Storost-Vydūnas, who presents his view of the decline of the Pruzzen in his polemical work Sieben Hundert Jahre deutschlitauischer Beziehungen ${ }^{9}$. It is worth noting that Bobrowski's preference for using the word Pruzzi (and similar forms) was probably deliberate, historically motivated and reflects his propensity for using archaic spellings (as in the title Litauische Claviere).

The term Pruzzi (later also referred to as Prutheni and Borussians) was first used in the 10th century and had spread throughout Europe by around 997. Only after the German Cistercians had succeeded in Christianizing some Prussians, appointing the monk Christian as first Bishop of Samland with the help of the Polish Duke Konrad of Mazovia in 1215, did the Pruzzi turn against the Christian religion, ousting the bishop. Only in $1225 / 1226$ were they conquered by the German Order. Despite uprisings in 1243 and 1260, the Western Balts were conquered in long-lasting battles (1231-1283) with the resulting decimation of the population. The remainder became serfs (cf. the fate of the Livonians, approx. between $1287-1581^{10}$ and gradually linguistically Germanized. Haufe makes note of the fact that Bobrowski's wife, Johanna (née Budrus), was of Pruzzi origin. Beside German she spoke Lithuanian. However, the sparse inclusion of Lithuanian words suggests that he may not have relied on her for Lithuanian equivalents whilst compiling his $P V$. There is no indication in Haufe's detailed chronology as to the dates within which the $P V$ was completed (cf. below). On the other hand

${ }^{9}$ Wilhelm Storost-Vydūnas (Vilius Storost-Vydūnas): Sieben Hundert Jahre deutsch-litauischer Beziehungen. Kulturhistorische Darlegungen, Tilsit: Lithuania 1932. Erw. Nachdruck Chicago: Akademinès skautijos leidykla 1982. Zweite Auflage. The abbreviated title (Sieben Hundert Jahre) refers to this edition. - Although Haufe, $J B 1$ XIV, is sceptical about possible parallels between Vydūnas and Bobrowski, there is reason to infer that Bobrowski was possibly influenced by his (Vydūnas') critical view of the Teutonic Order, cf. K. Brazaitis: 'Bobrowski's Lithuania. Papers given at the Conference "Johannes Bobrowski 1917-65", Reading, 23 September 1995. Ed. J. Wieczorek. Occasional Papers; No. 2 Reading, esp. 16-28;17-36.

${ }^{10}$ Blumbergs, Andrew James: The Nationalization of the Latvians and the Issue of Serfdom. The Baltic German Literary Contribution in the 1780s and 1790s. New York: Cambria 2009. 
his works, especially Litauische Claviere, illustrate the use of a substantial number of Lithuanian words and proper names.

\subsection{History of the Old Prussians}

The oldest records concerning the Old Prussians suggest that they traded amber (Latin glaesum) with the Romans, the Celts and the Vikings. They subsequently experienced a strong influence from Viking military culture in the Sambian peninsula and coastal area between the 9 th and the beginning of the 11th century. Never completely wiped out by the crusading knights, they amalgamated with the German tribes and later with other ethnic groups (Lithuanians, Poles, Flemings, French etc.), forming a new German-ruled Baltic Prussia.

After the wars with the Order had come to an end, the eastern side of the area was inhabited by Eastern Balts, whilst the Sambian peninsula and the areas to the west and to the south were inhabited by Western Balts. Under German rule, the West Baltic tribes were treated as one Prussian nation, with which, however, the Lithuanians of Lithuania Minor gradually merged. The West Baltic tribe of Old Curonians occupied further territories in both modern West Lithuanian and West Latvia. These subsequently merged with the Lithuanian and Latvian nations. Later on, a part of the Latvian-speaking Curonians migrated to the Curonian spit and lived there until their deportation after 1945.

Baltic Prussia, usually referred to as West- and East Prussia, is generally known as part of the historical German Prussian state with its capital in Berlin-Brandenburg. The north-eastern part of Baltic Prussia, in the cartographical literature of the 18th century, was normally called Prussian Lithuania (Preußisch Litauen) and, in the works of Simon Grunau, from the 15th to 16th century, Lithuania Minor or, in German, Klein Litauen, or more commonly PreuBisch-Litauen ${ }^{11}$. It extended roughly from the south eastern coast of the Baltic Sea to the Masurian Lake District. After the First World War part of Lithuania Minor north of the river Neman (Lith. Nemunas) was incorporated into the Republic of Lithuania. It was then called the Klaipeda Region (German Memelland). After the Second World War the remainder of the former West-

${ }^{11}$ Reklaitis, Povilas: Kleinlitauen in der Kartographie Preußens. Ein Beitrag zur Geschichte des Gebietsnamens Litauen im ehemaligen Königreich Preußen. Studia Lituanica III. (A Collection of Studies on her History and Ethnography). Ed. Martin Brakas. New York, N.Y., 1978. 
and East Prussia was divided between Poland, the U.S.S.R. and Soviet Lithuania (Lithuanian S.S.R.). In recent times a new 'Prussian Movement' (originally called the 'Brotherhood Prūsa', Prūsas Brātrija in revived Prussian) has emerged both in the Polish- and Russian-speaking territories of former East Prussia in the hope of restoring elements of Baltic-Prussian ethnicity as well as the Old Prussian language, thereby aiming to reconcile the new inhabitants with their land as well as with the original inhabitants, who had formerly been deported ${ }^{12}$.

The name Prüsa is the old Baltic name of the land we now know in the Latinized form-Prussia (Preußen is a later phonetic development of the name *Prūsai 'Pruzzen'). Copious anthroponymic and hydronymic terminology has been used by scholars, notably the archaeologist Marija Gimbutas, to indicate former Old Prussian habitats. Some 160 Proper names (within 82 entries in $O P G$ ) have been included in Bobrowski's $P V$. Most geographical names of this area were Germanized in late Middle Ages but some one thousand Baltic names of localities were replaced by Soviet Russian names after incorporation of the northern part of former East Prussia into Russia by the Soviets

${ }^{12}$ Initial attempts to revive OP for the sake of verification of theoretical reconstructions lead to Experimental Prussian (1984) after Palmaitis and Toporov had published their Manifesto on the revival of Prussian in the same year (see Selected Bibliography, Articles). A keen interest in the Western Baltic tribes (Old Prussians), their language and culture among some former inhabitants of pre-war East- / West-Prussia, in both Lithuania and Latvia, Poland and Russian Kaliningrad (former Prussian Königsberg), was another motive for this experiment, as well as for the establishment of the Club PRUSA in Lithuania in 1988. This club developed its 'filias' in neighbouring countries, later forming an association named the 'Brotherhood Prūsa' in 1990. Further political changes, new frontiers and growing local patriotism stopped the first wave of this movement. However young people of the new post-war generations in Polish and Russian parts of former East Prussia gave birth to the second wave just several years ago. Linguistic principles of the revival of Prussian on the basis of Samlandian were created (http://donelaitis.vdu.lt/prussian/princip.htm). Today 12 persons speak a revived version of Old Prussian, and an OP Reader was published in 2007 (cf. Prusiska Chrestomatija in Selected Bibliography). A Grammar of Modern Prussian, as well as a seven-language dictionary, are readily accessible on the web (cf. Selected Bibliography, Websites, esp. http:// wirdeins.prusai.org. 
(e.g. Lith. Tolminkiemis, Russian Чистые Пруды [Tschistye Prudy]). The Poles, for their part, restored many Baltic names which had been replaced by new German names during the German period.

\subsection{Culture and social status of the Old Prussians}

A large body of archaeological and historical evidence allows us to form a rich picture of the cultural, economic and social status of the Old Prussians (more precisely referred to as Western Balts) in pre-historic and historic times, although, as is typical for early and mediaeval historiography, it is a mixture of fact and fable. Accordingly, the Old Prussians who were in the main on record for being peaceful (according to Adam of Bremen and others), upheld economic ties well beyond their home territory, which brought them as far south as Greece and the Roman Empire.

The Western Balts had an agricultural culture, grew rye, barley, wheat and beans (cf. Bobrowski's entry 'bean' (66 babo 'Bohne'). In addition to their agricultural activities they were engaged in hunting, fishing and beekeeping, all of which are reflected in Bobrowski's $P V$. Their craft skills included metal-working, weaving, wood-carving and pottery. Most fortresses were built in strategically important areas, which were later taken over by the Crusaders, who fortified them using bricks ${ }^{13}$. By the time the Crusaders arrived in the 13th century, the Western Balts had reached a high standard of material welfare. We also have some information about their religious beliefs and practices ${ }^{14}$. The Western Balts were involved in seafaring activities, with their ships reaching the Swedish shores. Part of them were at first known as Aistians, and only around 845 and thereafter does the name Bruzi emerge (according to an anonymous Bavarian cartographer). Early information about the Western Balts has also been supplied by writers and historians (such as the Russian Nestor, Polish Gallus, and Kadlubek and the much travelled Anglo-Saxon, Wulfstan, in the late 9th century). In particular the chronicler Peter von Dusburg, a German writer of the Middle Ages (Chronicon Terrae Prussae, 1326) describes the religion of the

${ }^{13}$ Lietuviu Enciklopedija, Boston: Lietuvių Enciklopedijos Leidykla; vol. 24, 'Prūsai', 136-162; (abbrev. $L E$ )

${ }^{14}$ Cf. Marija Gimbutas: The Living Goddesses. Ed. \& suppl, by Miriam Robins Dexter: Berkeley and Los Angeles: University of California 2001, 197-213. 
Pruzzi, i.e. their belief in a gods / goddesses, as well as sacred places and heathen cults ${ }^{15}$. He ascribes to the leader / chief of the Old Prussian tribe, Lith. krive, the office of a priest. According to other chronicler, Simon Grunau (cf. subsequent studies on this topic), the Old Prussians worshipped three gods: Pykoll, Perkunas (cf. Bobrowski's 336 percunis 'Donner') and Patrimpe. Pykoll, reflected in the Third Prussian Catechism (KIII) as picküls 'devil' and closely related to the word 'hell' in Bobrowski's $P V$ (336 pyculs 'Hölle', cf. La. Pikuls, 'heathen god'), was a god of the underworld, and was also named Patollo.

We learn that the Western Balts included pagan priests as well as a richer and a poorer class (cf. Bobrowski's word for 'king': 201 konagis 'König'). The richer folk drank mare's milk (cf. Bobrowski's 32 aswinan 'Stutenmilch'), whilst the poorer and the slaves partook of mead, of which they could drink their fill; however beer was also produced. In later sources the richer people were called the nobles (Latin nobiles, potentes; German die besten).

\subsection{Language and literary sources of Old Prussian}

As stated above and established in scholarly literature (E. Haufe, R. Sinkevičienè), one of Bobrowski's sources was the Elbing Dictionary $(E)$, whilst the other major source was a translation of Martin Luther's Enchiridion (the OP translation is called Catechism III; abbrev. $K$ III, discussed below). Only in rare cases is the source uncertain or indeterminable nor are there many instances of Words of uncertain origin (Appendix B). Additional sources are Proper names (abbrev. PN) and include names of localities as well as family names. In 1922 Georg Gerullis investigated over $1000 \mathrm{PN}$ relating to the OP areas of settlement ${ }^{16}$.

The Old Prussians spoke Old Prussian (OP), a so-called Western Baltic dialect. Archaeological data support the division of Baltic tribes into Western and Eastern ones. OP is closely related

${ }^{15}$ Peter von Dusburg: Scriptores rerum Prussicarum. Leipzig, 1861-1874, Vol. 1-4. (Abbrev. SRP) - Zenonas Ivinskis (1939): 'Dusburg, Peter': LE Vol. 5, Ed. J. Kapočius; Boston: Lietuvių Enciklopedijos Leidykla 1955, 266-267. - For a comprehensive description of the OP Criwe, including detailed quotations from the sources, cf. 'Criwe' in: Kazimieras Büga: Rinktiniai Raštai 1 170-179.

${ }^{16}$ Georg Gerullis: Die altpreußischen Ortsnamen, Berlin und Leipzig; Walter de Gruyter, 1922; (abbrev. Gerullis 1922). 
to Lithuanian and Latvian, sometimes referred to as Litu-Lettisch in German research. Both belong to the Eastern branch of the Baltic group of Indo-European languages. Together with Old Curonian and Yotvingian (also called Sudovian), OP is classified as belonging to the Western branch of the Baltic languages, even though the evidence for Curonian and Yotvingian is sparse. The Middle Ages took little interest in the OP language of the people (lingua vulgaris). Even the Catholic Church did not initially spread the Gospel to newly Christianized Western Balts in their native tongue. Not until the rise of Protestanism during the Reformation did the need for translated material firmly establish itself. These translations are invaluable as they testify to both the OP culture (Dusburg i.a. above) as well as the OP language (Nesselmann i.a. below) and have been discussed in detail in scholarly literature.

Firstly, there are the glossaries and three Catechisms, as described below. These became available as 19th century photographic reproductions, then in later 20th century editions (or part-editions):

\subsubsection{The so-called Elbing dictionary (E)}

\subsubsection{History of the E glossary}

The oldest OP document is $E$ which was one of four documents included in the Codex Neumannianus, named after its discoverer F. Neumann (1792-1869) in 1825. The whole codex was part of the estate of A. Grübnau (1740-1823). Neumann donated it to the Elbing Library, after which the document was named, the call number being Q 84. The documents were in the safekeeping of the Elbing Library till the Second World War. Vytautas Mažiulis wrote in 1966 that the whereabouts of the codex was unknown to $\operatorname{him}^{17}$.

The codex includes four documents in all: three legal documents (the law of Lübeck, the law of Pamede, the old Polish law) and $E$. The whole codex consists of 186 pages, of which 185 pages have been written on, while the last page is empty. The last 17 pages, $169-185$, include $E$. The pages were numbered by $F$. Neumann. The manuscript had been copied by Peter Holczwesscher (Explicit per manus Petri Holczwesscher De Mai'en Burg, ibid). Holczwesscher, probably a German monk of the Teutonic Order, not understanding OP, copied the manuscript

${ }^{17}$ Vytautas Mažiulis: Prūsų kalbos paminklai, Vilnius, vol. 1 1966, 27-31. 
using the Gothic script, which was called the 'monks' script' [Mönchschrift] from the original or its copy, most probably at the end of the 13th century or at the beginning of the 14th century. Nothing is known about the original mansucript. According to G.F.H. Nesselmann, one of the notable nineteenth century scholars of OP, it was probably also written by a German belonging to the Order, probably using German-Latin glossaries, which were popular in the Middle Ages, changing the Latin into OP words.

\subsubsection{Editions of $\mathrm{E}$ (and other OP glossaries)}

The earliest edition of $E$ stems from G.F.H. Nesselmann (1868), and was published under the title Ein deutsch-preussisches Vocabularium $^{18}$. It was followed by the publication of Bezzenberger and Simon (1897) who supplied a reliable photographic reproduction of the existing facsimile, which a subsequent editor, R. Trautmann (1910), deemed ganz vorzüglich ausgeführt und [....] ein vollständiger Ersatz des Originals, and which has provided an important source for Prussologists. The work on further editions continued. Foremost were also Reinhold Trautmann's own edition Die altpreussischen Sprachdenkmäler $(1910)^{19}$ and Mažiulis' Prūsú kalbos paminklai, (Prussian literary monuments, Vilnius, 1966-1981; abbrev. PKP 1 or 2) edition, which includes Trautmann's photographic reproduction of $E^{20}$. Subsequently in 2007 an English edition including the very same facsimile titled Old Prussian Written Monuments and edited by

${ }^{18}$ G.F.H. Nesselmann: Ein deutsch-preussisches Vocabularium aus dem Anfange des fünfzehnten Jahrhunderts. Königsberg 1868, quoted in Lothar Kilian: $\mathrm{Zu}$ Herkunft und Sprache der Prußen. Mit Wörterverzeichnis Deutsch-Prußisch, 1982, 2. erw. Aufl. Bonn: Rudolf Habelt, 74-77. - Kilian, ibid, gives an overview of more significant publications dealing with OP, beginning with Christoph Hartknoch's work Dissertatio de lingua veterum Prussorum in 1679, and finishing with V. Mažiulis' PKEŽ 1-4, which forms one of the key references for the present work. - Hartknoch's work Preussische Kirchen-Historia, publ. 1686 , is of particular interest as it was one of the books kept in Bobrowski's personal library, cf. Bukauskaitè, 2006, 274-275, cf. Select Bibliography.

19 Trautmann, R: Die altpreussischen Sprachdenkmäler. Einleitung, Texte, Wörterbuch. Göttingen: Vandenhoeck \& Ruprecht, 1970, 2nd edition, unv. Auflage.

${ }^{20}$ V. Mažiulis: Prüsų kalbos paminklai (Old Prussian Written Records), Vilnius: Mintis. Vol. 1-2. 1966-1981. 
Letas Palmaitis, followed (cf. Select Bibliography). The difference between this and Mažiulis' PKP 2 is that Mažiulis provides a literal, line-by-line translation of the OP Catechisms (into Lithuanian), in order to demonstrate the authenticity of the OP versus the deviating Baltic constructions. Only essential foot-notes and explanations have been added. Palmaitis, by contrast, presents an analagous literal OP translation (into English) and includes an entire reconstruction of the text with foot-notes and explanations. Undoubtedly the most authoratitive, as far as dictionaries go, is the four-volume edition of the Prüsü kalbos etimologijos žodynas (Old Prussian etymological dictionary, Vilnius, 1988-1997; abbrev. $P K E Z \check{Z}$ ). However, whereas this work primarily focuses on etymology, Letas Palmaitis' analogous dictionaries include translations into several languages. His two electronic web versions (abbreviated as $O P D$ and $T D P$ ) have been followed by a printed one $(L B V)^{21}$, all based on the $P K E Z^{22}$. The sources mentioned in the above section form the vital basis of the present work.

\subsubsection{The content of E in Bobrowski's PV}

Bobrowski makes frequent references to fauna and flora in his works. Many of these can be traced to $E$, which comprises 802 entries. There are 56 names of mammals (7\%), 67 bird-names (8.4\%), 25 fish-names (3.12\%), 10 arthropods (1.25) and 7 names of reptiles and amphibians $(0.88 \%)^{23}$.

$E$ begins with the words Deywis ('God'), Rapa ('angel'), Lauxnos ('stars'), Deynayno ('dawn'), and concludes with Pintis ('road'), Lonki ('path'), Posty ('pasture') and Sardis ('pen [for

${ }^{21}$ The two web versions by the same author are both based on V. Mažiulis' $P K E \check{Z}$, and provide very similar information, with minor differences appearing in the treatment of accents and inclusion of equivalents in other languages. Compare, for example, the $L B V, O P D$ and TDP for Bobrowski's 257 luriay 'Meer': a) entry in $L B V$ (cf. Select Bibliography, Dictionaries): 'JÜRJÄI nom pl Luriay E 66 / jūra / jūra / Meer / morze / sea / Mope JÜRJAN acc sg iürin';

b) entry in OPD (cf. Select Bibliography, Websites): 'JÜRJĀI nom pl Luriay E 66 / jūra / jūra / Meer / morze / sea JÜRJAN acc sg iūrin';

c) entry in TDP (cf. Select Bibliography, Websites): 'JURJĀI nom p1 Luriay E 66: Meer / sea JÜRJAN acc sg iūrin 107: Meer / sea' [as OPD entry but excludes Lithuanian, Latvian and Polish cognates / equivalents]. ${ }^{22} \mathrm{Cf}$. Letas Palmaitis in his introduction to the $L B V$.

${ }^{23}$ Cf. V. Blažek, V. J. Celadin and M. Betakova: 'Old Prussian Fishnames', Baltistica XXXIX (1) 2004, 107-125. 
cattle]'). The words are not listed according to the Latin alphabet but are entered according to associated, thesaurus-like groups. Bobrowski has included selections from $E$ only. Mažiulis, in his discussion of $E$ entries, gives the example 'year' ( $E 12$ Jor$M e t t a n)$, followed by 'summer' ( $E 13$ Somer-Dagis), 'autumn' ( $E$ 14 Herbist-Assanis), etc. (Mažiulis, $P K P 128$ ). The first word in $E$ is in German followed by the OP equivalent (the reverse is true for Bobrowski), and is preceded by a large capital red letter (not reproduced either in the photographic version or Mažiulis' and Palmaitis' editions, these being exact copies of Trautmann's, which in turn, is an exact photographic reproduction of the Bezzenberger and Simon 1879 edition, cf. above). The words vary in size and virtually no attention is paid to such concepts as shipping, farming, fishing or religious terminology, which is remarkable, considering these were important features of the old Prussian culture. Mostly nouns, both concrete and abstract, have been included, there are no verbs here. Bobrowski, for his part, does include such words, which he presumably collected from the language of the Enchiridion (cf. 6.3. below).

3.6.1.4 Place of writing and the dialect of the Elbing Vocabulary

The place of writing could have been Pomesania (Lith. Pamede) or, even more likely, Marienburg, where there were two collections / codices of the laws of Lübeck, Lith. teisynai, acting in accordance with the law of Lübeck ( $E L V 439$ ). The hypothesis that the dialect of $E$ is Pomesanian ('pomesanisch') has, on the whole, been substantiated by scholarly research. It has been convincingly argued by Gerullis 1922 (272-274). It is all the more plausible because $E$ contains quite a few Slavic words and, besides, this area was additionally inhabited by Poles and Germans ( $E L V$ ibid). Also, certain names of localities (e.g. OP Pupain, German Pupehnen EL ibid) tend to confirm that OP had a word for 'bean', (66 babo 'Bohne', a Slavism, as mentioned above). A number of forms require further investigation and it is to be queried whether they are of a dialectal or phonetic nature, e.g. the ending in cawx (pronounced [kauks], 'devil'), may be contrasted with vilkis ('wolf'), the $u$-stem neuters alu ('beer') with meddo ('honey'), whereas the a-stem neuters, e.g. assaran 'lake', correspond exactly to the form in Bobrowski's list, lunkan, etc. $E$ is also older from the point of view of the Baltic vowels $\bar{e}, \bar{i}, \bar{o}, \bar{u}$, which are unchanged/ stable, (e.g. OP wetro, Lith. vétra, 'wind'), whereas in the Catechisms there are some changes to $\bar{i}$, ei, $\bar{u}$, ou (e.g OP $\bar{i} d i n$, 
contrasted with Lith. edi, EL ibid). According to Palmaitis, the Samlandian dialect of the Catechisms represents a kind of Prussianized Sudovian (Yotvingian), so that it may be regarded to be a language differing from $E$ (see Select Bibliography, Articles).

\subsubsection{Simon Grunau's Prussian Vocabulary:}

OP lemmata are furthermore included in a compilation of some 100 individual words, collected by Simon Grunau, (so-called Prussian vocabulary, abbrev. Grunau), published approx. 1510$1529^{24}$. Grunau sympathized with the indigenous Western Balts and pointed to the fact that they spoke a different language from the Germans (Preusch [sey] ein besonder sprache, in LE XXIV 151). The language, according to some Prussologists, had been 'distorted' and included some Polish as well as Lithuanian words (e.g. Lith. eikete [cf. dialect form eiki tę]'go there']). There are, furthermore, words that do not occur in other OP documents: e.g. malkos 'logs of wood', pawtte 'testicles'; lynno 'linseed', manga 'whore' and salme 'straw' (ibid). There are four manuscripts, only one of which is available in the Göttingen University Library ${ }^{25}$. Grunau is of little significance for Bobrowski. Whereas only one facsimile of the latter is available at the aforementioned Library, we have verified photographic copies of $E$ in various editions and one on the Web.

\subsubsection{The Catechisms}

The second important source for Bobrowski's $P V$ are the texts of Catechisms I, II, III (abbrev. K I, II, III). The first two were printed in quick succession in Königsberg in 1545, the third in $1561^{26}$. Whereas the first consists only of six pages of OP text, with

${ }^{24}$ Simon Grunau: Preussische Chronik. Ed. M. Perlbach, Leipzig, 1875. Publisher unknown.

${ }^{25}$ V. Mažiulis: Prūsų kalbos paminklai... cf. footnote 21, above.

${ }^{26}$ All known OP texts have been reprinted in Vol. 1 (and commented upon in vol. 2, pp 65-134) in V. Mažiulis' PKP as follows: vol. 1 1966: Catechismus I, p. 81-95; Catechismus II, p. 97-111; Der Kleine Catechismus $I I I=$ Enchiridion, 113-246. Cf. also in the last edition by L. Palmaitis (Old Prussian Written Monuments, see Select Bibliography): Catechismus $I$, p. 105-131 (including reconstruction), commented on 132-144; Catechismus II, p. 147-173 (including reconstruction), commented on 175-187; Der Kleine Catechismus III $=$ Enchiridion, $\mathrm{p}$. 
the second being a corrected, supplementary version, the third one consists of 55 pages of OP text. This is a translation of Martin Luther's Enchiridion by Abel Will. In most cases only $K$ III is relevant for Bobrowski. (Whereas the Enchiridion relates to Luther's German version, the OP translation refers to $K I I I$; these are not entirely identical, with the Enchiridion containing other texts, such as i.a. Duke Albrecht's greetings to his Prussian Getrewen unterthanen).

We have considerable information about relevant manuscripts and facsimiles relating to the Enchiridion. The text was first published by Johann Daubmann in Königsberg, but the number of copies is unknown. Until the Second World War the Enchiridion was housed in the Königsberg University Library (called $K$ copy). It consisted of 134 unnumbered pages and included a dedication to Duke Albrecht in German. The text, which included a German and Old Prussian text, consisted of a very literal translation of Luther's Catechism with formulae which were to be used whilst performing marriage and Baptism Rites. The final page features the coat of arms of the Prussian State. The fate of this document is unknown, although there was a lively discussion about it in scholarly literature, notably in the works of Trautmann and Nesselmann, to whom there are passing references in Bobrowski's $L C{ }^{27}$. Excerpts from $K I I I$ form a prominent feature of annotations accompanying this edition.

\subsubsection{Disparate lexical items}

Finally, included in non-OP documents, i.e. in German, Prussian, Polish and Lithuanian sources, are disparate lexical items in fragmentary form, dating between the 13th and 16th centuries, containing, in some cases, German glosses of OP words ${ }^{28}$.

191-434 with including complete reconstruction and annotations. - The Enchiridion is the most important of the three Catechisms for Bobrowski's glossary: - Enchiridion. Der Kleine Catechismus Doctor Martin Luthers / Teutsch und Preussisch. Gedruckt zu Königsberg in Preussen durch Johann Daubmann. MD LXI.

${ }^{27}$ For all further details of the Enchiridion cf. Mažiulis, $P K P 239-40$. These include information about the publication in 1543 of Luther's Enchiridion (KIII) and the translator Abel Will, as well as his limited knowledge of OP, ibid.

${ }^{28}$ Cf. 'Fragmentai', PKP 1, 29-31 also Old Prussian Written Monuments by L. Palmaitis, $437-438$ ). 
Although most of the glosses are irrelevant for Bobrowski, one of the words, i.e. the placename Gailgarben, is included as a PN in Bobrowski's PV: $126 \mathrm{gal}$ 'Burg' Gallgarben. Another source from the beginning of the 15th $\mathrm{c}$. is a fragment of the Lord's Prayer. Several words are comparable to Bobrowski's entries: e.g. Towe (503 towis 'Vater'); andangonsün (84 dangus, dangonsun 'Himmel') and swyntins (414 swints 'heilig'). 


\section{METHODOLOGY FOR THE ANALYSIS OF $P V$}

The complete compilation of Bobrowski's $P V$, (cf. Appendix $A$ ) forms the essential component of the present work. It is styled $A n$ Old Prussian Glossary (OPG) in contrast to Bobrowski's own $P V$ and includes all of Bobrowski's OP headwords, followed by their German meanings. Some of Bobrowski's headwords are supplemented by an inclusion of OP Proper nouns $(\mathrm{PN})^{29}$.

There are essentially three main pieces of information, which follow each one of Bobrowski's entries (prefixed by sequential numbering by the writer) and include Bobrowski's entry of PN. This and two examples of an entry are outlined below. The chief literary OP sources are the reprinted OP documents and sources, which include the Elbinger Vocabulary and the Enchiridion, following Mažiulis as explained above. The secondary sources include dictionaries such as Julius Pokorny's Indogermanisches Etymologisches Wörterbuch (Pokorny), Ernst Fraenkel's Litauisches Etymologisches Wörterbuch (Fraenkel), V. Mažiulis' $P K E \check{Z}$ and Letas Palmaitis' Lexicon Borvssicum Vetvs (LBV). Finally, the corresponding, at times, reconstructed headwords of the $L B V$ have been included for the sake of comparison and are of interest, especially since they include succinct items of information, e.g. both the deviating $O P$ reconstructions, the morphological, etymological and grammatical explanations and / or reconstructions as well as Lithuanian, Latvian and English equivalents of the headwords. The present work also relies heavily on Gerullis' authoritative collection of OP Names of localities ${ }^{30}$. As already pointed out, Mažiulis' seminal $P K E Z ̌$ and $P K P 2$ provide invaluable information regarding grammatical, morphological and semantic explanations for the lexical items as well as citations from $K I I I$ but have not all been included in the

${ }^{29}$ Cf. Gerullis' detailed discussion of a large number of OP Names of localities; he emphasizes the great variety of Lesarten and provides orthographic variants of these: Die altpreußischen Ortsnamen esp. 214225. - Indispensable is also his treatment of such aspects as phonology (214-224), word formation of OP PN (225-264) and his compilation of PN occurrences in the documents of the Teutonic Order (275-286), still relevant in 1922 and presumably till 1945, when these names were russified.

${ }^{30} \mathrm{Cf}$. above note no 29 . 
present work. It has been necessary to exclude much information for the sake of emphasising Bobrowski's own contribution to the $P V$.

In most cases Fraenkel's Etymologisches Wörterbuch gives the three languages, i.e. OP, Lithuanian and Latvian, predominant attention, even though there is little attempt to assume a common Baltic reconstructed form. Pokorny, who concentrates on the common IE ancestry, enters first the reconstructed ie. root morpheme, followed by the related languages, which are divided into separate IE language groups, e.g. Baltic, Germanic, Romance and Slavic. Within these the Baltic examples are usually placed together. Whereas both Fraenkel (restricting himself to Lithuanian) and Pokorny (including a wide-ranging IE context) forego the reconstruction of common Baltic forms, historical linguists specializing in Baltic languages (e.g. Endzelins, Mažiulis) do so, providing the reconstructed IE stems, often commenting on 'older' versus 'later' forms among the three. However, among these, Mažiulis is unique in that he has introduced a new method of precise etymological research, which includes a definition of the derivational base. Such an approach is not the aim of the present work. It must also be specifically pointed out that the current work does not aim at presenting an Old Prussian-English dictionary per se. Nor is it, as already mentioned, an attempt to reconstruct roots or discuss IE and OP reconstructions. For this the reader is referred to specialist literature in the works of past and present Prussologists, including the most recent publications of Letas Palmaitis (cf. Select Bibliography, Dictionaries, Glossaries, Grammars [...] Websites).

The current work consists of methodical annotations following a set formula (below) as well as of concrete references to sources, including $E$ and $K I I I$, quoted verbatim from the sources, thus providing relevant contexts for each lemma and specifying possible areas of interest for Bobrowski.

The words in the present work follow Bobrowski's order, which, as observed above, does not adhere to the strictly conventional alphabetical order. As in Bobrowski's $P V$, there are no entries under $\mathrm{f}$, h. Words beginning with $\mathrm{c}$ and $\mathrm{k}$, expressing the velar [k] are, as in Bobrowski, grouped together. There are no words beginning with $\mathrm{o}, \mathrm{q}, \mathrm{x}$ or $\mathrm{z}$.

To recapitulate, the entries in this edition follow the principle of providing three items of information as may readily be 
substantiated with reference to relevant dictionaries and sources which have been noted in the Select Bibliography.

\subsection{Method of annotation}

Bobrowski's lemmata are numbered from 1 to 583. Each entry contains three main pieces of information:

a) The presumed source (PS, eg. $E, K$ III) is supplemented by a Lithuanian translation and an abbreviated entry cited from the $L B V$ and $O P D$ (cf. Bibliography and List of Abbreviations and Symbols);

b) Inclusion of Bobrowski's PN, i.e. in the main toponyms (names of localities), hydronyms (river, sea and lake names) and anthroponyms (first names and family names, cf. Appendix B). Four major sources have been consulted for this purpose: Gerullis, LTV, Peteraitis and Progenealogists (from 04. 03.09 to 30.10.09), cf. Select Bibliography.

c) Both Old Prussian (and / or Baltic / West-Baltic root), Lithuanian, Latvian and (other) Old Prussian equivalents as well as Indo-European roots. In some cases IE and Latvian, less so Lithuanian, cognates could not be traced and are thus not included in each entry. In all cases the reader is referred to the consulted reference works (cf. Select Bibliography and List of Abbreviations and Symbols). This section, in a different style, is usually supplemented by a brief comment on the possible relevance of the headword for Bobrowski.

The purpose of the first item of information is to contextualize Bobrowski's own entries within related glossaries and available sources. The references to $E$ are usually in line with $P K E \check{Z}$. However, for details on historical word formation the reader is referred to Mažiulis' analyses and overview of literary sources dealing with OP words ${ }^{31}$. The entries contain the $E$ word, a modern German equivalent and the Lithuanian meaning. The $L B V$ and / or $O P D$ supplement this information. They include the relevant diacritics and an English translation of the OP word. The second item is a transcription of Bobrowski's Proper names (PN), contextualized within related sources. Finally, the third item of

${ }^{31}$ Mažiulis' entries invariably include not only etymological, semantic and morphological aspects, but also contain a detailed history of word derivation and references to important scholarly works and stress his own contributions. Due to the confines of the current work, I shall in rare cases only include comments on specific aspects of Mažiulis' entries. 
information gives both the diachronic and synchronic equivalents of Bobrowski's entries, based on abbreviated forms of OP as well as Lithuanian and Latvian equivalents, and IE ones, whenever possible. Diachronic refers both to $\mathrm{OP}$ and $\mathrm{IE}$ reconstructions taken from the sources, synchronic refers to actual verifiable (including occasional anachronistic and / or obsolete) Lithuanian and Latvian equivalents. All duplications (e.g. references to the PS in both $P K E Z \check{Z}$ and $L B V$ ) have been avoided for the sake of clarity. The usual convention of including three full stops to indicate omissions and asterisks has been adopted throughout. Round brackets are used for cross-references. Square brackets have been reserved for editorial comments and explanations in contrast to the author's text as well as to enclose a word / phrase substituted by the editor for the original one(s) in quoted material. The $L B V$ and / or $O P D$ entries have at times been included for Lithuanian and Latvian entries, even if they are not cognates, to indicate the 'movement' away from the presumed Baltic root.

The following paragraphs include two examples of an entry (cf. List of Abbreviations and Symbols):

(A) the first is a typical example of Bobrowski's $P V$ headword where the PS is $E$;

(B) the second illustrates a headword, where the PS is $K I I I$; the headword has been quoted within the relevant context, whenever possible: the OP, German (Luther's Enchiridion) and Lithuanian text (Mažiulis' translation) enable both a comparison of the relevant headword as well as the contextual contrast and comparison of $\mathrm{OP}$, Lithuanian and German parallel versions :

(A)

4 assaran 'See'; Assaunen

b) PS: $E 60$ assaran 'see (=See)', 'ežeras', nom.-acc. sg. neut., PKEŽ1 104;

$L B V:$ AZARAN $n$ Assaran: See $m$ / lake;

b) PN: "1318 Azara "Sumpf im Samland" ', Gerullis 11; Lith. P1. N. Zarasai < *Azarasai with West-Baltic (Selonic) $z=$

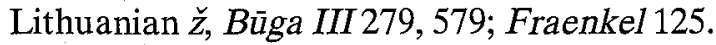

Assaunen ('1384 Assun', Gerullis 12) is unrelated to OP assaran : the German spelling with doubled ss in assaran was chosen to mark shortness of the first vowel a-, not to render the sound / s / instead of actual / z / (cf. Lithuanian 
and Latvian samples). As for '1384 / '92 Assun', later Assaunen, Kr. Gerdauen, Gerullis refers to the anthroponym Assune (Gerullis 12) which may originate from Alsune (Trautmann PN 12), what in turn is comparable with Lith. alsà 'tiredness', alsúoti 'to pant (breathe)';

b) < OP *ezaran, PKEŽ 1 ibid;

Lith. ẽžeras (dial. ãžeras), La. ȩzȩrs 'lake', 'See', Fraenkel ibid; $P K E \check{Z} 1$ ibid. According to Mažiulis, the word is only available in Balt. and Slav. languages, ibid.

$<\mathrm{IE}^{*}$ eghero- 'Landsee', Pokorny 291-292.

BOBROWSKI'S WORKS INCLUDE NUMEROUS REFERENCES TO WATERY SURFACES (SEA, LAKES, ESPECIALLY TO RIVERS AND THEIR TRIBUTARIES WITHIN HIS SARMATIA). NUMEROUS POEMS ARE SPECIFICALLY DEDICATED TO THE 'PRINCIPLE' OF THE RIVERS (E.G. 'DIE JURA', DIE DÜNA', 'DIE MEMEL' ETC., CF. WIECZOREK 1999, 65-74; IN PARTICULAR CF. REFERENCES TO CRITICAL LITERATURE DEALING WITH THE THEME OF RIVERS, $I B I D)$.

(B)

120 ernertiuns 'erzürnt'

a) PS: $K$ III: ernertimai 'erzürnen', / 'inirtiname, įpykiname', $P K E Z \check{Z} 1$ 287, e.g. (within Confession Rites Luther's explanation that the person who is confessing his / her sins, be this the father, mother etc., must confess having caused another person to become angry): As[-]mai stans ernertiuns / bhe prei klantisnan pobanginnons; 'Habe sie erzürnet vnd zu fluchen bewegt'; 'esu juos užnirtinęs ir prie keiksmo pajudinęs, $67: 32$ / 69:1-2, PKP 2151.

$L B V$ : ËRNĒRTĪWUNS > Ėrnērtīmaī $p c p t$ ac nom $\mathrm{sg} \mathrm{m}$ ernertiuns 694; ernertiuns 69; cf. ERNERTİMAİ ps 1 pl ernertimai 31: erzürnen, ärgern / irritate;

b) PN: none;

c) < OP *er- ${ }^{*}$ nertītvei 'nirtinti, pykinti', < OP subst. ${ }^{*}$ nerti- < Balt. verb *ner(t)- / ${ }^{*}$ nir $(t)$ - 'to demonstrate own

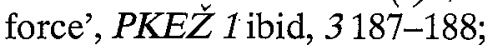

Lith. nir̃sti and niřšs $t$ 'to become enraged', 'heftig zürnen, ergrimmt, aufgebracht, wütend sein', Fraenkel 504-505;

< IE: Balt. (verb) *ner( $t)-/$ nir $(t)$ - < IE dial. *ner $(t)-/$ $n r(t)$ 'to be potent' $P K E Z 3188$.

BOBROWSKI'S PV FEATURES A CONSIDERABLE NUMBER OF WORDS RELATING TO THE RITES OF CONFESSION, BAPTISM, 
MATRIMONY AND EUCHARIST, ENABLING US TO FREOUENTLY PINPOINT THE CONTEXTUAL FOCUS OF HIS INTEREST AND HIS READING. 


\section{LITHUANIAN AND OLD PRUSSIAN THEMES}

Whilst a variety of studies have confirmed that Bobrowski's output is closely linked to Lithuanian themes ${ }^{32}$, there are only scattered references to the way Old Prussians left their mark in both his lyrical and prose works. Old Prussian history, mythology, a large variety of toponyms, as well as the diverse fauna and flora so important in populating his 'landscape with people', have enriched Bobrowski's oeuvre.

In his poem GS (Dead Language) Bobrowski includes four words from the Old Prussian written records, altering three words slightly, possibly for reasons of metre, rhyme etc., even though in his own $P V$ he follows the spellings in the $E$. Thus he writes Laurio, (whereas the $E 66$ has luriay 'Wasser'), wittan 'Weide' (instead of $E 603$ witwan), smordis 'Faulbaum' (instead of the $E$ 612 smorde). The only word which is identical with $E$ is the word Warne (E 722 warne 'Krähe' [crow]).

In another poem $N V$ Bobrowski includes two more OP words: 151 gerwe 'Kranich' in an unaltered form (as in $E$ no 715 ) and 3 angurys 'Aal' ( $E 565$ angurgis, usually considered an 'error'). Haufe's detailed chronology of Bobrowski's life and works makes no mention of the activity of collecting the words or the intention of publishing these. It is possible to speculate that his interest in the Baltic area remained consistent over a considerable period of time. Both his works Sarmatische Zeit and Litauische Claviere (1965, Haufe, ibid, S. 150-51) were completed between 1962 and 1965. These and his poems $G S(17.4 .1960)$ and $N V(15.8 .1963)$, provide us with termini ante quem and post quem as possible dates of his $P V$. On the other hand, the uniformity of the writing indicate that he could have compiled his $P V$ 'in one breath', i.e. over a few days, even though the PN were presumably entered at a later date (cf. above).

${ }^{32}$ Although Old Prussian and Lithuanian themes, and, more specifically Sarmatische Zeit and $L C$, in Bobrowskis' writings have not been exclusively discussed by Lithuanians, several studies by Lithuanian scholars, especially on $L C$ and $S Z$, may be noted. They include, for example, in alphabetical order Kristina Brazaitis, Artūras Hermannas (Arthur Hermann), Vytautas Kubilius and Regina Sinkevičienè (see Bibliography). Significant is the recent publication by Dalia Bukauskaite (ibid). 


\section{$6 \quad P R U Z Z I S C H E$ VOKABELN AND CLASSIFICATION}

Bobrowski's 583 entries can be compared to the list of 802 words in $E$ and the vocabulary of the Enchiridion ( $K I I I)$. Whereas Bobrowski lists his words alphabetically (not very strictly), beginning with the OP word for river (1 ape 'Fluß' Angerapp), the $E$ entries begin with the German word for God : $1^{\prime}$ Got' Deywis. The entries in $E$ by contrast are not alphabetical but are placed in thematic groups like in a Thesaurus. The following compilation of thematic groups in Bobrowski gives a breakdown of the words, using semantic and formal-morphological / grammatical criteria. A lexical analysis shows that Bobrowski's $P V$ can be divided into five thematic, semantically viewed, groups (cf. 1.The legacy..., above). 


\section{SUMMARY AND CONCLUSION}

The following comments draw some conclusions from the groupings. By tracing the frequency of words within defined thematic groups we have a valuable instrument for a consideration of their relevance for Bobrowski's themes. Such findings would be further enhanced were we to have a concordance of all German words within Bobrowski's creative works. Bobrowski's themes are closely associated with the words for water, sea, lakes and rivers. The inclusion of three $\mathrm{PN}$ for his entry no. 2 abse Espe; Abschwangen, Absmedien, Abschruten, for example, indicate that he was familiar with these from either his geographical or literary sources, and had visited one, Abschwangen, on April 28 / 29, $1933^{33}$. He also includes a considerable number of words which represent a selection of wild and domestic animals.

Apart from the emphasis given to fauna and flora as well as to the religious themes, a large number of words relate directly to the sphere of the human being, and more specifically, to the people of East Prussia. Their way of life, the products of their labours as well as their activities and occupations mirror Bobrowski's immediate interests. Various classes and social strata are represented. This interest in humanity and their endeavours, make the concept of Bobrowski as a humanist all the more meaningful. In addition to the defined areas of interest, he has included 163 OP PN, as is indicated in a large number of toponyms, hydronyms and anthroponyms, which, in many cases have parallels in both Lithuanian and Latvian (cf. Appendix B).

\subsection{Principle of selectivity}

In both of his sources ( $E$ and $K I I I)$ Bobrowski has made a conscious selection of OP words. Words taken from the Enchiridion were guided by their meaning in context. Inflectional forms were rarely entered and only included if they were essential for comprehension ${ }^{34}$. We discover here that more emphasis is, for example, given to lexical items relating to the Rites of Baptism and Matrimony, less so to those of Confession and the Eucharist. $E$ words were, on the other hand, selected because of their intrinsic interest. Thus, for example, he excluded all the words for the week-days (E 18-22), only retaining the word for 'Sunday'. Very

33 Eberhard Haufe: Bobrowskis Chronik. Daten zu Leben und Werk. Würzburg: Königshausen und Neumann, 1994. 
specific words for parts of the body ('vertex', 'forehead', 'back of the head', 'nape of the neck $E 76-80$ ), were also omitted, as were words for 'kidney','gut', stomach', 'bladder', 'gall' ( $E$ 128-135).

A similar procedure can be observed for his exclusion of some animals, trees and plants. Nor are all names for family members, parts of the body and societal concepts included. Only a concordance and the study of usage of the lexical items and their German equivalents within relevant contexts of Bobrowski's oeuvre hold the key to establishing more firmly what guided his selection of Old Prussian and Baltic lemmata.

The results of human activity, be this producing things or building towns and villages or dwellings to house people or animals, have been recorded. Bobrowski reflects on his own life and experiences of his homeland, East Prussia. His selection allows him and the reader to concentrate on specific areas, which I

${ }^{34}$ Bobrowski's selection does not proportionally mirror his sources (cf. Appendix B, Statistical overview). He selected 583 words out of approximate 2,500-3,000 OP (cf. Kilian, Mažiulis' PKEŽ) lexical items. Although $E$ includes some 200 words in the area of fauna (I Fauna \& flora), Bobrowski has only listed some 78 words. Flora, in $E$, is represented by some 100 words, whereas Bobrowski has 70 entries (ibid). There are 58 words in Bobrowski's next group (II Religion); they are basically derived from the Catechisms, especially the Enchiridion (K III), where they are represented by roughly three times that amount. Other groups (III-V) have not to my knowledge previously been defined in the typological sense that I have undertaken for Bobrowski (cf. Introduction). For the final Section (VI Proper nouns) we have an even further problem, since proper names, are, by and large, absent from both $E$ and $K I I I$. The following table represents a rough approximations of numerical occurrences both in Bobrowski as well as in his two major presumed sources, the $E$ and $K I I I$. This is done for the words relating to the first two groups only, whereas the remaining groups, indicated by a dash, could possibly be included, but for the purpose of comparison, remain undefined:

\begin{tabular}{|l|l|l|l|}
\hline & Bobrowski & E & K III \\
\hline A Fauna \& Flora & 145 & 200 & 600 \\
\hline B Religion & 58 & 50 & $200 ?$ \\
\hline C Inanimate & 87 & - & - \\
\hline D Grammatical Items & 164 & - & - \\
\hline E The Sphere of the Human Being & 176 & - & - \\
\hline F Proper Nouns & 160 & - & - \\
\hline
\end{tabular}


have classified semantically, according to such areas as family and the larger aspects of society, focusing on both the literal and figurative meaning. This is to be viewed in the context of the East Prussian culture and history.

As Haufe's chronological presentation of Bobrowski's day-today activities and the exploration of his homeland whilst a schoolboy and a young man indicate, Bobrowski was keenly aware of the details of his surroundings. Critical literature has often remarked on the writer's interest in the landscape of his homeland and the fact that his writings, especially those relating to the Sarmatische Ebene, have biographical roots, as he himself explicitly notes ${ }^{35}$. Names of places and their surroundings speak of you (Namen reden von dir, $P E, J B 1,35$ ), he says in addressing the landscape, rocks and plants. These are directly addressed and are stylistically reminiscent of the Lithuanian dainos, which frequently identify the "lyrical I" with her / his surroundings ${ }^{36}$. This gives his work a quality reminiscent of the pantheism that we find in the English Romantics (Wordsworth, Keats). The universe, nature and God, are united in his scheme of things. However, Bobrowski, like the German Romantic poets, emphasizes feelings and expresses the subjective faculties of the mind. On the other hand, he explicitly distances himself from German Romanticism with its glorification of nature as such, adding his own understanding of social Engagement, stressing throughout his works and in interviews the need to relate literary works to contemporary social and political conditions. This he states for instance in an interview with the Deutschlandsender ${ }^{37}$. Even though he freely admits that literary works are of political relevance for his day and age, he accepts transcendental truth and the authority of the Bible and the teachings of the Lutheran Church.

\subsubsection{The sphere of the human being}

Human concerns, represented by words in his fifth group (Classification $V$ : The sphere of the human being), are one of the most important motivating forces in Bobrowski's writings. Terms of endearment, so well represented in the diminutives within the

${ }^{35}$ Regarding the strong biographical nature of his poetic discourse cf. Sinkevičienè, Regina: 'Ein paar Paraphrasen...', 2004, 399-411.

${ }^{36}$ Arturas Hermannas (Arthur Hermann): 'Dainų įtaka ... (1978), 177182.

${ }^{37}$ 'Vom Hausrecht des Autors', in: JB Selbstzeugnisse, 1976, 43 passim. 
Baltic languages, include the expression for 'small / dear man' / 'fellow' (575 wirikan 'Männlein'). Blood and / or conjugal relationship ('mother', 'father', 'brother' and 'sister'), prolific in many related IE languages, as well as the words for more remote relationships ('stepfather'), have been listed. Unusual in his $P V$ is the word for 'aunt', for which Bobrowski enters an archaic meaning (287 moazo 'Muhme'), subject of much etymological interest ${ }^{38}$.

A large group has an exhaustive listing of parts of the body ('heart', 'liver', 'tongue' etc.). Unusual are the words for 'eye-ball' and 'nostril'. The next group includes products / instruments, constructions / buildings, all resulting from human activity. Quite a few words reflect Bobrowski's interest in the agricultural sphere. Implements ('hayrack', 'sickle') and buildings / structures ('mill', 'shed') are included.

Noteworthy is the list of instruments / implements such as those for sewing, cutting, shaping and picking up objects, such as coal embers, sewing devices such as 'bodkin', 'needle', 'thread', 'chisel', 'nail', '(iron) pot'; 'knife'; 'chain'; 'pliers', 'tongs' are part of an expanded list (cf. 356 peilis 'Messer', also Lith. peilis), a significant attribute of one of the characters in $L C$. Useful implements around the house and farm are the 'skewer' and 'rope'; bulding materials include the 'plank', useful items such as the 'comb' and 'brush' and manmade / manufactured materials are exemplified by such words as 'leather'. Items for human comfort include a special type of chair, used both in East Prussia and Lithuania (cf. 241 kresil 'Stuhl', Lith. krèslas).

The importance of the horse and associated words is apparent in a considerable list ('saddle', 'hoof', 'bit' [horse's], 'horse-shoe'). The horse is a significant ingredient of Baltic folklore, featuring specifically in numerous folk songs. Example of food ('honey') and drink ('mare's milk') as well as the generic word for nourishment, reflect everyday needs. Outdoor activities, essential for supplementing food supplies, are represented by the word for the 'hunt'. Items of clothing and footwear include 'boot', 'trousers' ('to

${ }^{38}$ Krzysztof Tomasz Witczak: "Old Prussian moazo 'mother's sister', mosuco 'weasel' and related words."' Baltistica XXXIX (1) 2004 131-139 (cf. Websites). OP moazo 'Muhme' is reminiscent of Lith. móša - 'the husband's sister' (Lith. 'vyro sesuo'), cf. German 'Schwägerin als Schwester des Mannes', La. mãsa 'Schwester', Preuß. moazo Voc. $178^{\prime}$ Mume' [...]." 
cover the thighs'), 'shirt', 'shoe' and 'sole of shoe'.

A variety of buildings are added to his list ('castle', 'mill'). Interesting in this context is the inclusion of Klete ( 211 klenan, 'Klete'), a room used for storing food ('granary'). The Klete, frequently discussed in sociological studies, was also used as sleeping quarters and reflected a way of life peculiar only to East Prussia, Lithuania and Latvia. Bobrowski defines the OP klenan as German loanword 'Klete', 'granary'. It is not included in modern German dictionaries. The word for the 'mill' is of central significance for the author's Levins Mühle, and places of socially organized life ('town' and 'village') are also here. Parts of dwellings are, beside the Klete, the words for 'window', 'roof' and 'wall'. Dwellings and related concepts include the words in the specific meaning of 'structures for domestic animals (especially in winter)' and also 'shed (for cows / horses and pigs)' as well as feeding devices for these ('trough'). Within the words relating to society and social standing, we find such concepts as 'knight' (538 waldwico 'Ritter)', a professional fighting man and the word 'king' (201 konagis 'König'), which refers to a ruling nobleman (duke, king). These words are followed by a representative of the clergy (236 klausiweniki 'Beichtiger'), at the other end, including the word for 'country' (512 tauto 'Land' < IE *teutā Volk, Land', Pokorny 108). Representatives of military organizations include the aforementioned 'knight'.

However, most of the available OP words, for armour and weapons, as listed in $E$, have not been entered (40) ${ }^{39}$. More copious by contrast are words from the agricultural and occupational spheres with a list of such 'peaceful' occupations as 'ploughman', 'saddler', 'smith' , 'shoe-maker' and 'translator'.

\subsubsection{Abstract terms and concepts}

There is a considerable religious focus in the $P V$, as borne out by the collection of religious terminology (Appendix $B$ ). During his time in Königsberg Bobrowski was strongly influenced by a Christian upbringing at home and at school. Not only was he an active member of the Bund Deutscher Bibelkreise (which disbanded itself in 1934) but he also joined the Bekennende Kirche, which opposed the nationalistically inclined Deutsche Christen, who rejected the Old Testament and 'Jewish' elements of

${ }^{39}$ Regarding Bobrowsk's antipathy towards militarism, expansionism and colonialism cf. my article: Brazaitis (1995), cf. note 33, above. 
the New Testament ${ }^{40}$. Bobrowski's works show a good knowledge of the scriptures and a strong influence of the Bible as well as the creeds of the Reformation. Though we have no records that he owned a copy of Luther's Enchiridion in German, we can safely assume that a copy of both the German and OP (possibly Trautmann's edition?) was available to him.

He possibly compared and contrasted both texts, copying keywords and including them in his $P V$, a method he may have applied whilst learning Latin and Greek. This is common practise when reading texts in foreign languages. It is also important to note that a copy of Der kleine Katechismus was available in his personal library in Lithuanian translation. Page seven of this edition includes an excerpt from the Vaterunser in Lithuanian. It is quoted in $L C$ ( $G W 3263)$. Apart from this sparse inclusion of several words in $P V$, there appear to be no inclusions, nor are there underlinings or markings on the margin, in contrast to his other readings, where he used pencil or marker to highlight his focus of interest ${ }^{41}$.

Bobrowski's group of religious lexical items constitute abstract concepts (Appendix $B$ ) and attributes to accompany the words for

40 J. Wieczorek 1999, 4.

41 Dalia Bukaustkaitè: Kommentierter Katalog der nachgelassenen Bibliothek von Johannes Bobrowski. Trier: Wissenschaftlicher Verlag 2006, 435, quoted as follows: "D. Martino Luteraus mazas kategismas, ir d. Jono Jokubo Rambako pamokslas apie Ißganimo Dowada pirma 24 Klausimüse trumpay suglaustas, potam 237 Klausimüse placziaus ißguldytas." (English translation: "The Small Catechism of Martin Luther and the Sermon of Jonas Jokubas Rambakas on the gift of salvation, firstly in 24 short questions then extended to a further 237 questions") Szilokarcziamoj; Heydekrug: Buchdruckerei Artur Sekunna, 1922, 435. There are no Lithuanian equivalents for words from the Small Catechism in Bobrowski's $P V$. However, Bukauskaite notes that the writer quotes the beginning of the Lord's Prayer from this in his $L C(J B 3,262)$ : 'Téwe musu, kurs esi Dauguje'. Bobrowski had a detailed knowledge of both the OT and the NT. In addition to his Lithuanian version of the Small Catechism his library holdings included no less than three editions of the scriptures: 1826 edition of Die Bibel oder die ganze Heilige Schrift des Alten und Neuen Testaments (no. 160 of his library holdings), a 1909 edition (no. 161) and a further edition of the New Testament (year not available). Even a cursory glance enables to establish the context and concepts that interested him, as the writer included markings and underlinings in red and green pencil as well as ink, ibid. 48-55; 612-624. 
God, Mary with Bobrowski's entry (279 mergo 'Jungfrau', virgo, Maria), departing from the given $E$ meaning, for which Bobrowski includes, in addition to the meaning unmarried woman, the translation 'virgin' (erroneously from Greek) and the addidtional Maria. In his $P V$ three words are entered for Christ and one for Mary. Here Bobrowski is presumably following $K I I I$. Religious words include three of the so-called 'last four things' (Resurrection, Heaven, Hell), which are part of Christian eschatology, whereas the word for the Last Judgment is not included, though this concept is at least implicitly available in OP liga: 'Gericht, Urteil' (cf. 'court [of justice]', 'conviction', 'sentence [judgement']).

Some of the words for Christian faith and practice, which are included in his $P V$, reflect Bobrowski's sources and interest in various Rites / Sacraments (Baptism, Confession, Matrimony, Eucharist). Included are also the Credo, the Lord's Prayer and various Instructions to the community of the faithful. Related OP concepts were possibly coined at the time of translation and already in use prior to the translation of the Enchiridion whereas some could have been newly introduced by its translator, Abel Will. The date of possible inclusion of specifically religious terminology gives us the approximate date terminus ad quem of mid- 15 th century ${ }^{42}$. Many scholars point out that although old Prussian was used by Protestant pastors, the standard of familiarity with the language was limited. Pastors would probably have had to rely on the tolke, the translators, a word for which is also listed in Bobrowski's $P V$ (cf. 501 tolke 'Dolmetscher').

Bobrowski includes terminology relating to the Christian theological system and to Christian virtues (such as 'faith', 'belief'), also listing the opposites, i.e. the vices (such as 'sin', 'lack of faith'). The Christian virtues listed include the concept 'temperance' and 'moderation' (41 aulaikings 'enthaltsam'). However, in the absence of literary sources, it is impossible to presume if such concepts, probably introduced after the Christianization of the Old Prussians, had formed a firm part of the spoken language and hence value system, prior to the translation of the Enchiridion into OP. Also uncertain is to what extent the Prussians retained their

${ }^{42}$ Algirdas Matulevičius: Mažoji Lietuva XVIII amžiuje. Lietuvių tautiné padètis. Vilnius: Mokslas 1989, 31-38. 
early beliefs, even though scholars like to highlight the endurance of the Baltic beliefs and practices ${ }^{43}$.

Nevertheless, Bobrowski's OP vocabulary includes a variety of words representing the sphere of Christian values. Whereas these words are not exclusive to Christian ethics, the concept of 'mercy' / 'grace', at the core of Protestant theology, is used in a Christian sense (110 etnistis 'Gnade'), stressing the doctrine of justification (salvation) by / through faith. During a critical phase in Bobrowski's life he claimed in a letter to Werner Zintgraf he was living by grace ('Ich lebe aus der Gnade', Haufe, $J B 1$ XXXVII). $\mathrm{He}$ also includes two of the three cardinal virtues, eloquently propounded in Pauline writings, those of faith, hope and charity, of which the last, though available in the Catechisms, is, somewhat surprisingly, missing in Bobrowski's $P V$. Vices include the concepts of 'sin' (164 grikenix 'Sünder' grikans 'Sünden'), revenge, shame and that worst of all evils, 'despair' (392 perdwibugusnan 'Verzweiflung'). Bobrowski's concepts of grace, moderation and forgiveness are contrasted with sin and sinfulness, both expressing the extremes and ambivalence of Christian dogma.

In view of the fact that Bobrowski tends to follow his sources, it is not surprising that his $P V$ uses only few words to refer to the clergy, the servants of the Church and the parishes. These words can be traced mostly to $K I I I$. Of the words for bishops, monks and priests / pastors there are only the words for bishop and pastor. In Bobrowskis $P V$ only two words relating to the Christian Church as hierarchy / organisation (e.g. 239 cristionisto 'Christenheit') are included; there is one possible reference to the upper clergy / authority (40 aucktimmisku 'Obrigkeit'); one word for Priest / Confessor (236 klausiweniki 'Beichtiger'), mentioned above; one for parish ( 363 peroni 'Gemeinde') and, furthermore, a general group relating to the clergy as servant(s) of the Church (481 schlusnikan 'Diener'). The very few words for Christianity, priests, and parish listed by Bobrowski are of foreign extraction and were probably introduced by OP at an early stage but were most probably not used in everyday spoken language. The practice of preaching sermons in the churches by priests in the language of the indigenous population stemmed from Martin Luther. He advised his pastors to take note of how the 'common folk' spoke and to apply this to their translations (man mus die mutter im hause, die

${ }^{43}$ Gimbutas / Dexter 2001, 197-213. 
kinder auff der gassen, den gemeinen man auff dem marckt drumb fragen und den selbigen auff das maul sehen, wie sie reden ${ }^{44}$. Such an explicit instruction had strong resonance and undoubteldy penetrated to lands comparatively new to Christianity. This is well borne out by Duke Albrecht's lengthy letter to his Prussians, as noted above ${ }^{45}$.

Bobrowski's $P V$ contains some surprises. The first one relates to words from OP mythology. He rarely includes these, even though some OP words are available (e.g Bangputtis etc) and are to be found within the context of Litauische Claviere and Sarmatische Zeit. The only exception is the word for 'thunder' and the 'god of thunder', accompanied by one place name: 338 perkunis 'Donner', Perun (cf. III Inanimate Natural Features \& Phenomena). However, even here, in Bobrowski, the reference is to inclement weather rather than to the OP deity. On the other hand, Bobrowski's works include references to the Baltic deities Laima, Patrimpas, Pikolos. Some scholars argue for the authenticity of the Baltic pantheon ${ }^{46}$.

Another surprise is the selection of words which are not per se religious but the very fact of being within a religious context indicates that their inclusion reflected Bobrowski's interest in certain aspects of Lutheranism. These include vocabulary relating to the Rites of Baptism, Matrimony and Confession, as pointed out above. A good example is the above example of 'angered' (120 ernertiuns 'erzürnt'). It is entered as a past participle within the formula of confession, where the sinner confesses, that he / she has not served God faithfully and has angered him: Asmai stans ernertiuns / bhe preiklantīsnan pobanginnons (cf. above). In the present work this headword is classified as Grammatical items (Appendix B), even though semantically and / or contextually it could be seen as belonging to the class of religious words.

\subsubsection{Grammatical Items}

A large group of non-nominal items (Classification $I V$ : Grammatical items: Verbs, Adjectives / Adverbs; Prepositions etc.) make up the next group under consideration. In nearly all cases, the words are taken from the Enchiridion, a religious

${ }^{44}$ Hans Eggers: Deutsche Sprachgeschichte. Das Frühneuhochdeutsche. Vol. 3. Reinbek bei Hamburg: Rowohlt, 1969, 164-172.

${ }^{45}$ Cf. Enchiridion, PKP 291-100.

${ }^{46}$ Cf. Gimbutas / Dexter 2001, 197-213, 199-214. 
publication dealing with the Decalogue (Ten Commandments), the Credo, the Lord's Prayer and the formulas of Baptism and Matrimony. As I have already suggested, some of the related terminology could have been introduced at the time of the translation of the Enchiridion, whilst other lexical items were probably derived from already existing lexemes and in most cases, were probably taken from every day speech. There is thus at a first glance nothing specifically religious about such as the sub-group of verbs (4.1.) classified under Infinitives, ('to die', 'to be', 'to fear', 'to give'), Imperatives ('stop!') or Past participles ('received', 'buried'). The second sub-group (4.2.) consists of Adjectives and Adverbs ('true', 'sober', 'in the morning', 'temperate', 'high' / 'tall', 'firm', 'certain(ly)', the colours ('white', 'blue', 'red', 'black'). The third sub-group (4.3.) comprises Prepositions ('without', 'out of', 'over' / 'above'; 'in front of'). The fourth sub-group (4.4.) consists of Numerals (1-10), Articles and Pronouns. The Numerals are limited to the first ten numbers plus 'thousand', including a mixture of cardinal and ordinal numbers, e.g. 'one', 'the second', 'the third' etc. The so-called "Definite article", added by Bobrowski himself, is entered only once, in its oblique, dat. sg., form ( 522 tasmai 'dem').

On closer scrutiny Grammatical items frequently relate to various themes of the Rites / Sacraments and other aspects of $K$ $I I I$, as observed above. Interesting are one-off occurrences in $K I I I$ (often entered in an inflected form only e.g. (152 geide 'er wartet'). In some cases Bobrowski entered several forms of the same word (146 giwato, giwei, giwan / giwammai; 251 krixtits, crixtnis, cristionisto ), as he encountered them. Two or more words are often placed within one entry, even though the words appear in different contexts (e.g. 104 endyritwai, endiris, endeirit, each appearing in the contexts of Baptism, Confession and the Lord's Prayer, repectively). Of note are words which, due to their exact match in $K I I I$, give us a clear indication of the exact context within which Bobrowski would have read the word, then entering it into his $P V$. In one instance, for example, we read within the Baptismal Rites the following sentence: bhe wissans vndans prei Deiwütiskan austkandinsnan bhe laimiskan aumūsnan stēisan grijkan swintinninuns; "vnd alle Wasser zur seligen Sindtflut vnnd reichlichen $A b$ waschung der Sünden geheyliget', $119: 25-26, P K P$ 2227 . Within this context alone, we can trace as many as seven words, which the writer took up in his $P V$ selection. 
Contextualising all words and relating them to the themes of the $K$ $I I I$ has given us a handle to the particular contexts of $K I I I$ from which the writer took his selection. The result points to his particular focus on the Rites of Baptism, Matrimony, the Lord's Prayer and Luther's Instructions to the faithful. His interest in the rite of Baptism is reflected in his novel $L M$ and forms the background for the differences of interpreting this Sacrament among the Baptists and other sects in Malken. Less predominantly represented are words relating to the rite of Confession, the Eucharist, the Credo, the Morning and Evening Prayers, and the Decalogue.

It is not surprising that Bobrowski, with his interest in West Baltic geography and history, has included a copious listing of some 160 OP PN, entering them next to the headword, as noted above. It is not unlikely that such an interest resulted in the collection of OP words in the first place. These frequently depart from those in Gerullis, the author of the seminal work on Old Prussian placenames (cf. note 15). They often relate to fauna, e.g 'swan' (Pagulbinnen), 'crane' (Gerwen, Gerwenkehmen); 'earth swallow' (Krixtegallen); 'magpie' (Sarkau) and 'crow' (Warnecke.). Of the several fish names, even the word for 'eel' is accompanied by a PN (Angerapp). Terminology relating to the Flora category and, in some cases items pertaining to natural phenomena within it, are also at times followed by toponyms and hydronyms. Although OP toponyms are meticulously compiled, they have not by and large been included in his opus, even though caution is in place, as no concordance is available as yet. On the other hand, Bobrowski's propensity for including toponyms is a marked characteristic of his writing. German and Lithuanian (as well as Russian and Polish) PN, usually but not exclusively represented by German equivalents, have been recorded, in some cases in various languages. Some of these include the words for the river German Memel, Lith. Nemunas (cf. his Russian word Nemen) is mentioned frequently, with Bobrowski usually referring to it as 'the River' ('Strom'). The river is a marked leitmotif of his lyrical output. Towns, cities and villages are frequently mentioned (Kaunas, Vilnius, Tolmingkehmen, Šauliai). The equivalents of German OP PN (often available in Lithuanian and Latvian parallel forms) of umpteen villages may be located in $L C$ (they are usually Germanized: Gumbinnen, Stallupönen; Willkischken, Moritzkehmen, Prussellen, Pogegen, Polompen, Lasdinehlen, 
Absteinen, Tolmingkehmen.) His description of places, often forming the background to those relating to characters, and the specifications of their geographic location, has frequently been remarked upon ${ }^{47}$. Such inclusion of $\mathrm{PN}$ in his oeuvre is part and parcel of a conscious and effective technique, because he strove for authenticity, as he himself stressed. It is probably not unreasonable to hypothesize that Bobrowski could have planned the incorporation of further words, which he had compiled into his prose or lyrical works. His OP anthroponyms include such Lithuanian names as Selmike, Magusce, Lina Warszus. There are quite a few Lithuanian hydronimics (in addition to Nemunas, he includes, for example, the rivers / tributaries Bartuva, Jura, Szeszupe). These lexical items vary in quantity. Bobrowski was familiar with them either on the basis of his own experience or from maps and his wide reading, which included selections on East Prussian geography and history, as well as a collection of Louis Nast's Lithuanian folk songs ${ }^{48}$.

Bobrowski's $P V$ does not concern itself with establishing the relationship between OP and the related East Baltic languages. This is in stark contrast to his interest in words used within his Lithuanian themes, which pervade his creative writings. A Classification of his $P V($ Appendix B) has indicated that there is a strong predominance of nouns in Bobrowski's opus, prompting some Bobrowski scholars to say that this results in a so-called nominalist style and the creation of a new language, strongly influenced by Hamann's poetic output ${ }^{49}$. Also unlike some 'collectors' of words, he does not pursue any defined linguistic aim but has been interested in relating them to his own poetic interests, as outlined above. Had he been motivated by historical and / or linguistic interest, his $P V$ would probably have included comparative, supplementary IE, OP, Lithuanian and Latvian entries as well as more morphological, lexical and etymological and semantic material. As it stands, the Lithuanian words, with a couple of exceptions, are not added to his $P V$. On the other hand quite a few Lithuanian lexical items, especially in $L C$, have been

${ }^{47}$ Reinhold Tgahrt (Ed.): Johannes Bobrowski oder Landschaft mit Leuten. Eine Ausstellung des Deutschen Literaturarchivs im SchillerNationalmuseum Marbach am Neckar. Marbach am Neckar: Deutsche Schillergesellschaft. 1993, $690 \mathrm{ff}$.

${ }_{48}$ Bukauskaite 2006: 489.

${ }^{49}$ J. Wieczorek 1999: 38 and $137 \mathrm{ff}$. 
included in his writings (cf. the Lithuanian words marti, bernelis, dyvai, didelis peilis, sudiev, sveiki for 'daughter-in-law', 'young lad', 'wonders / marvels', 'big knife', 'good-bye', 'hello' (cf. Von nachgelassenen Poesien, JB 4, 19 ). As the current $O P G$ indicates, there is a very large number of words, in both Latvian and Lithuanian, which have a close affinity or are identical to the OP words (cf. 356 peilis, Lith. peilis, German 'Messer'). As in the case of PN, Bobrowski frequently inserted words in Lithuanian to give his prose local colour and a ring of authenticity, thus expanding his context to embrace a related Baltic language and culture (cf. his reference to the deities Laumen, Banpugtys, discussed above), without going into the minutiae of linguistic precision, bearing in mind his own comment that one of the OP words he used in GS (16.4.60) was a kind of reference or 'mental prop', having only 'Gedächtniswert' $(J B 5,34)$. Bobrowski made no excuses for his occasional lack of precision. Yet his own entries in his $P V$ reveal remarkable attention to the accuracy of orthography and basic meanings, gleaned from his sources. The knowledge of the meanings provided a firm foundation for his OP and Lithuanian themes. OP people, the landscape and, not least, the newly introduced Protestant ideology, are features of a language and culture, which virtually 'disappeared' at the beginning of the 18th century but nevertheless formed part of a significant cultural legacy for descendants of this area. Bobrowski consciously and selectively compiled roughly a fourth of the available lexical corpus to supplement what he already knew about the Pruzzi from historical and fictional sources from earliest childhood into adult years, both from the fields of literature as well as folklore.

How does Bobrowski's selection of OP words link in to his lyrical output? Let me attempt to sketch one exemplary answer. On the one hand the $P V$ is evidence of Bobrowski's intimate bond with the people of Eastern Europe, especially with the Lithuanians of East Prussia. Predominant landscape features for this region were moors, sunny fields and the yellow sand of the Baltic Sea, combined with the mournful story of sorrow and guilt. Landscape motifs were thus a weighty symbol of West Baltic history and its ultimate tragic fate, so eloquently expressed in the poet's elegy to the exterminated Volk Pruzzi: Dir / Ein Lied zu singen / hell von zorniger Liebe / deinen nie besungnen / Untergang (PE, JB 1,33). The word Volk, tabooed for obvious ideological reasons in West Germany at the time, is repeated seven times and is directly linked 
with the OP deities Perkuns und Pikolls / des ährenumkränzten Patrimpe (ibid, 34).

These concepts can be readily traced to the $P V$. On the other hand, Bobrowski did not wish to select any grand or exotic words for their own sake. He did not wish to simply write pretty poems, he said ${ }^{50}$. By the same token he did not simply want to collect words. With his selection the writer wanted to achieve something meaningful: he wanted to let his German compatriots know what kind of tragedy they had inflicted on history beginning with the Crusaders to the time of the Third Reich and to make them aware what guilt they bore on their shoulders. Nor did he exclude himself from this: he would stand with the rest, recognizable in his uniform. Each poem, each word, was to be expressive, it had to represent a mosaic, so as to produce a varied and multi-faceted complete picture. These elements 'translate' into varied segments / layers of meaning. Bobrowski thus achieves a remarkable synthesis of symbiotic relationships, and it is difficult to unravel symbol from meaning. Many such concepts are included in the corresponding OP $P V$ and have their equivalents in the corresponding German. If we just take one example of a poem - and many more examples can be found throughout his lyrical works - we find the equivalent concepts hawk, wolf, fish, sea in the OP PV: Mein Vater der Habicht. / Großvater der Wolf. / Und der Ältervater der räubrische Fisch im Meer (Lettische Lieder, JB 1, 57).

Did Bobrowski consciously evolve a code of words which represented such concepts as wolf (Nazi Germany), crow (death), fish (symbol of life), river (symbol of life, hope, vitality), which he consistently used in his German poems finding either similar or contrasting equivalents for these in his OP $P V$ ? Did he form a pattern of words at the time when he began to write his poetry on the Eastern Front in 1941, where, as a 24-year-old German soldier in Kaunas, he and others trod in der Wölfe Spur, driving away (D)ie grauen Züge - Greise und manchmal die Knaben - over a hill to their untimely death? ( $S Z$ : Kaunas 1941, JB 1, 60-61)? Did he at that time develop a firm set of concepts, which could bring back the vanished world of the Old Prussians and evoke the preChristian era of the gods and heroes of the ancient Prussians? His poems resonate with eloquent and picturesque descriptions of his

${ }^{50}$ For a thorough examination of Bobrowski's Sarmatian poems, cf. ibid, i.e. J. Wieczorek 1999: 33-97. 
homeland - its rivers, its forests, quiet villages, animals and birds ultimately leaving us with a sense of magic, mystery and a shattered dream of an old culture. Nor is this Romantik and vorbei ( $L C, J B 3,286$ ), for the writer is ever conscious of the shared responsibility for its decline and disappearance, expressing this theme of lament and elegy, especially in his lyrics: Dir/ ein Lied zu singen, / hell von zorniger Liebe- / dunkel aber, von Klage / bitter... deinen nie besungnen / Untergang... (PE, JB 1, 33).

As briefly indicated, Bobrowski's $P V$ opens up a new area for researching themes and their lexical representation both in the areas of concrete and abstract concepts. In a best scenario Bobrowski may have been planning to incorporate some lexical items into a new work. In another, undoubtedly useful scenario, his collection was to remain a mental prop, a reminder that an old culture, which leaves a vocabulary covering many areas of human endeavour, is a rich legacy, indeed. The knowledge of the OP language undoubtedly provided him with a firm foundation for his $\mathrm{OP}$ and Lithuanian themes. It is unlikely that this was to remain a mere spare time hobby. The additions of $\mathrm{PN}$ to his $P V$, entered in different writing and a different writing implement, at a later period, indicate this clearly. It is tempting to speculate that he may have contemplated a later expansion of his $P V$. 


\section{A GUIDE TO USING THE OPG}

Bobrowski's headwords and Proper names (PN) are in bold italic font. Katechismus III (K III) and Old Prussian (OP), German and Lithuanian parallel texts are taken from Prūsų kalbos paminklai (PKP 2). The OP text is specified according to section, verses and sources, e.g.: 65: 8-9, PKP 2147 = Section 65, lines 8-9, Prūsŭ kalbos paminklai, vol. II, page 147 .

\subsection{Divisions of $O P G$}

Each entry includes three main pieces of information:

a) Presumed Source (PS):

1. the Elbinger Vocabulary $(E)$; the $E$ entries begin with the first headword 1 ape 'Fluß' Angerapp and continue in relevant sections of the $P V$;

2. Katechismus III (occasionally and / or $K I, I I)$ : the OP translation of the Enchiridion, Luther's Catechism. The $K I I I$ entries begin with the seventeenth headword 17 arwis 'wahr' and continue in relevant sections of the $P V$; Bobrowski also includes some entries from $K I$ and $K I I$. To facilitate recognition, each occurrence of a lemma within its entry is bolded. In many cases, one occurrence of a lemma carries a diacritic (usu. a macron) and the other does not. In many cases an inflected form is included, in some there is a slight deviation in the spelling of the lemma. This is deliberate and in line with the sources.

3. $L B V$ and, less frequently, $O P D$, have been quoted using copy / paste facilities and provide additional aspects such as accents, variant orthography and morphological features. Omitted text in the citations is indicated by using the usu. convention of full stops within square brackets.

b) Proper nouns (PN: toponyms, hydronyms, anthroponyms):

1. The website Progenealogists;

2. Gerullis,

3. Other sources (e.g. PKEŽ 1-4, Pokorny, Fraenkel, LTV).

For sources and references cf. Select Bibliography, for abbreviations of frequently used termini, cf. Abbreviations and Symbols, below.

c) Indo-European (IE) and Baltic (OP, Lith., La.) etymology and equivalents: 
1. Each entry includes the OP reconstructed or documented form of the headword / lemma, as provided, for example, by Mažiulis and other Prussologists and Baltists;

2. Following each entry are Lithuanian or Latvian documented forms / equivalents of the headword / lemma. This section provides examples of documented / spoken language, but does not exclude archaic or obsolete forms.

3. This is then followed by the basic IE reconstructed root, as provided, for example, by Pokorny and other IndoEuropeanists. In scholarly literature IE is also referred to as Proto-Indo-European or Indo-Germanic.

\subsection{Guide to Citations}

Citations (from $P K P$ 2, Gerullis, Pokorny, $T D P$ etc. ): OP citation in italicized font; German and Lithuanian: single inverted commas; e.g. Ains nauns smūnets kas en tickrōmiskan bhe skīstieskan pirsdau Deiwan prābutskai giwa, 'ein newer Mensch der in gerechtigkeyt vnd reynigkeyt für Gott eweiglich lebe', 'vienas naujas žmogus, kuris teisungume bei skaistume prieš dievą amžinai (te)gyvena', 93: 19-20, PKP 2 146;

Citations within citations (double within single inverted commas; British practice); e.g.

< IE: *bhel-, "balto-slav[isch] "glänzend, weiß", auch von weisslichen Tieren, Pflanzen und Dingen', Pokorny 118;

Omissions are in square brackets; e.g. PS: $K$ III: 'pērdin (Futter) - pašarą [...] acc. sg. (hapax)', PKEZ̆ 3 260-261.

\begin{tabular}{|c|c|}
\hline $\begin{array}{l}\text { Abbre } \\
\text { Terms }\end{array}$ & $\begin{array}{l}\text { is / acronyms of Frequently Used } \\
\text { nbols (cf. Select Bibliography) }\end{array}$ \\
\hline$A L K \check{Z}$ & $\begin{aligned}= & \text { Bronius Piesarskas and Bronius } \\
& \text { Svecevičius: Anglu -Lietuviu Lietuviu - } \\
& \text { Anglu Kalbu Žodynas }\end{aligned}$ \\
\hline Būga $I, I I, I I I$ & $=$ Būga, K.: Rinktiniai Raštai \\
\hline$D L K \check{Z}$ & $=$ Dabartinis Lietuviu Kalbos Žodynas \\
\hline$E$ & $=$ Elbing Vocabulary \\
\hline$E L D$ & $\begin{aligned}= & \mathrm{Z} . \text { Belzēja, et al (Ed.): English-Latvian } \\
& \text { Dictionary }\end{aligned}$ \\
\hline Enchiridion & $\begin{aligned}= & \text { Enchiridion. Der Kleine Catechismus } \\
& \text { Doctor Martin Luthers }\end{aligned}$ \\
\hline Endzelīns & $\begin{array}{l}=\text { according to Endzelins, J.: Senprusu } \\
\text { Valoda (Also quoted as Jan Endzelin in } \\
\text { the sources) }\end{array}$ \\
\hline
\end{tabular}


Fraenkel

Gerullis

Grunau (Gr.)

GS

$J B 1-6$

$K I / K I I / K I I I$

$L B V$

$=$ E. Fraenkel: Litauisches Etymologisches Wörterbuch

= G. Gerullis Die altpreußischen Namen

$=$ according to / following Simon Grunau's Vocabulary

= Gestorbene Sprache (JB 126$)$

$=$ Johannes Bobrowski: Gesammelte Werke, vol. 1 - 6

$=$ according to $/$ following the Katechismus $I / I I / I I I(I I I=$ Enchiridion. Der Kleine Catechismus Doctor Martin Luthers)

$=$ Lexicon Borussicum Vetus (cf. Select Bibliography)

$L C=$ Litauische Claviere (JB $3225 \mathrm{ff}$.)

$L E=$ Lietuviu Enciklopedija (cf. Select Bibliography)

Lexer

= Matthias Lexer: Mittelhochdeutsches Taschenwörterbuch

$L T V$

$M L T V$

= Lietuviụ tradiciniai vietovardžiai. (cf. Select Bibliography)

= Pèteraitis, Vilius: Mažosios Lietuvos ir Tvankstos vietovardžiai. (cf. Select Bibliography)

$N f V$

$=$ Namen für den Verfolgten ( JB 1 191)

$O P D$

$=$ 'Old Prussian Dictionary' (internet source)

$O P G$

$=$ Johannes Bobrowski: Pruzzische Vokabeln. An Old Prussian Glossary. Introduced and edited by Kristina Brazaitis

$P E=$ Pruzzische Elegie (JB I33)

PKEŽ

$P K P$

Pokorny

Progenealogists

$P V$
= V. Mažiulis: Prūsu kalbos etimologijos žodynas

= V. Mažiulis: Prūsų kalbos paminklai

= J. Pokorny: Indogermanisches Etymologisches Wörterbuch

$=$ 'ProGenealogists. Family History Research Group; Records Retrieval and Ancestry Research'

$=$ Pruzzische Vokabeln (= Johannes Bobrowski's lemmata, incl.in $O P G$ ) 


\begin{tabular}{|c|c|}
\hline$S O D$ & $\begin{aligned}= & \text { The New Shorter Oxford English } \\
& \text { Dictionary }\end{aligned}$ \\
\hline$T D P$ & $\begin{aligned}= & \text { Trilingual Dictionary of Prussian } \\
& \text { (internet source) }\end{aligned}$ \\
\hline$T L \check{Z}$ & $\begin{aligned}= & \text { Tarptautiniụ Žodžiụ Žodynas, Ed. } \\
& \text { Algimantas Kinderys et al., Vilnius: } \\
& \text { Alma littera, 2003. }\end{aligned}$ \\
\hline$V L K Z \check{Z}$ & $\begin{aligned}= & \text { Vokiečiú-Lietuviụ Lietuvių-Vokiečiu } \\
& \text { Kalbų Żodynas. Deutsch-Litauisches } \\
& \text { Litauisch-Deutsches Wörterbuch. }\end{aligned}$ \\
\hline
\end{tabular}

8.4 Languages \& grammatical terms (deviating $L B V$ and other abbreviations are in brackets)

abstr.

ac.

acc.

adj. (aj.)

adv. (av.)

apr. (ap)

Balt.

balt.-slav.

c.n.d.

card. (crd)

dat.

drv.

ENHG

fem. (f)

FN

gen.

ibid

Idg.

IE

imp. (ip)

incl.

inf. (if)

jetzt
$=$ abstract

$=$ active

$=$ accusative

$=$ adjective

$=$ adverb

$=\mathrm{OP}$ (below)

$=$ Baltic

= Balto-Slavic (German 'baltisch-slavisch')

= could not be documented

= cardinal numeral

$=$ dative

$=$ derivative

= Early New High German (German 'Frühneuhochdeutsch')

$=$ feminine

$=$ family name

$=$ genitive

$=$ ibidem 'same place'

$=($ German 'Indogermanisch' $=$ IndoEuropean)

$=$ Indo-European (German 'Indoeuropäisch')

$=$ imperative

$=$ including

$=$ infinitive

$=\mathrm{OP} P \mathrm{PN}$ in / around 1922 according to

Gerullis, later changed to Russian names in / around 1945 


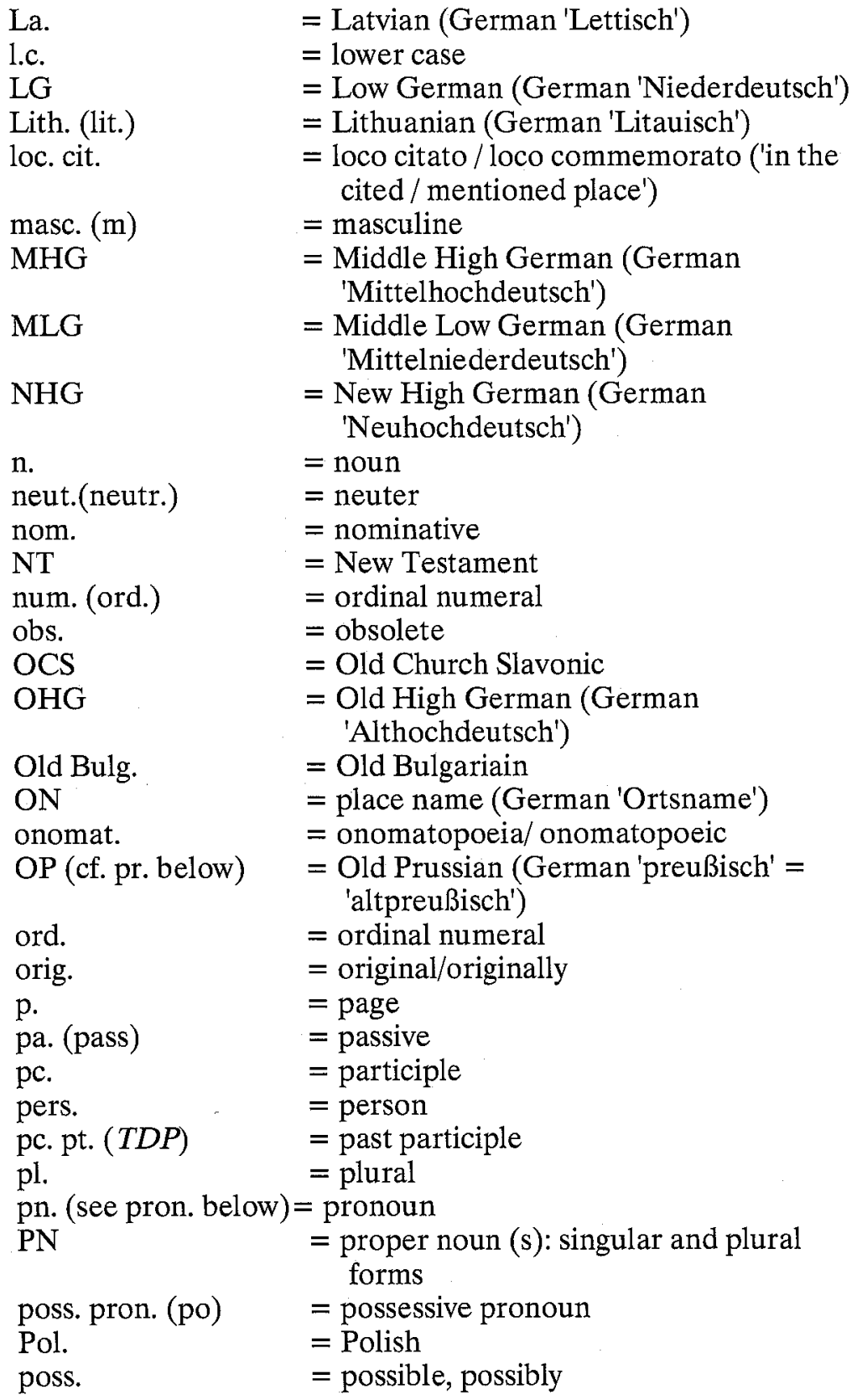




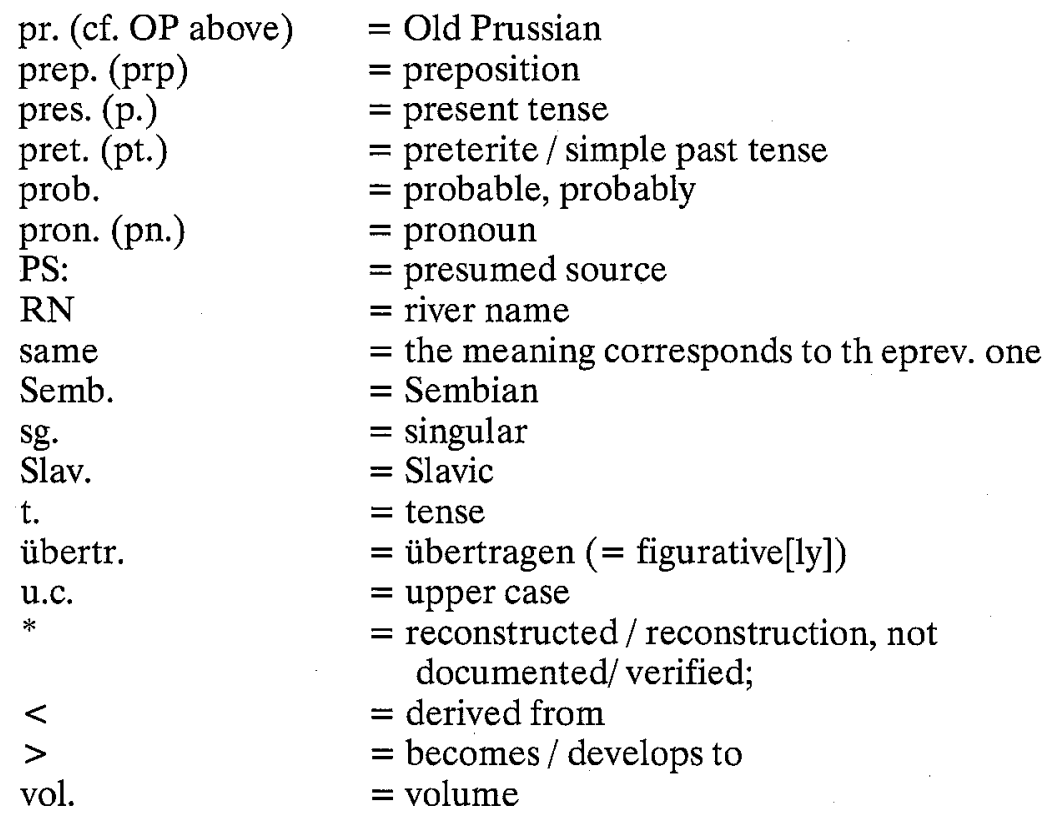

